University of Rhode Island

DigitalCommons@URI

Open Access Master's Theses

1977

\title{
Fox Point Development Plan
}

George J. Gefrich

University of Rhode Island

Richard C. Youngken

Follow this and additional works at: https://digitalcommons.uri.edu/theses

\section{Recommended Citation}

Gefrich, George J. and Youngken, Richard C., "Fox Point Development Plan" (1977). Open Access Master's Theses. Paper 625.

https://digitalcommons.uri.edu/theses/625

This Thesis is brought to you for free and open access by DigitalCommons@URI. It has been accepted for inclusion in Open Access Master's Theses by an authorized administrator of DigitalCommons@URI. For more information, please contact digitalcommons-group@uri.edu. 


\title{
FOX POINT DEVELOPMENT PLAN
}

a Masters research profect submitted in partial fulfiliment of the reauirements

for the degree of

Master in Community planning

\author{
by \\ George Joseph Gefrich \\ Richard Charles Youngken
}

University of Rhode Island 


\section{Introduction}

The Fox Point Development Plan is a Master research project. submitted in partial completion for the degree of Masters of Community Planning to the Graduate Curriculum in Community Planning and Area Development (CFAD), University of Rhode Island.

The Fox Point Development Flan consists of a package of four elements. These elements are:

(1) Analytical summary;

(2) Economic statement;

(3) Slide/tape synch promotional presentation;

(4) Scale architectural model of site plan with accompanying graphic material.

Presented here, in this document, are the analyticar sumnary and the economic statiment. All four elements of the project package have been submitted to the Graduate Curriculum in Community Planning, URI, and can be located under Curriculum direction. 


\section{Acknowledgements}

We would like to express our gratitude to the members of our Masters research project committee, Professor Dieter Hammerschlag, Professor Arthur Jeffrey, Professor John Kupa. and Albert Veri for their help and counsel. We would like to express a special thanks to Albert Veri and Dieter Hammerschlag for their invaluable guidance and enthusiastic support of this project. 
FOX POINT DEVELOPMENT PLAN

ANALYTICAL SUMMARY 
view of Downtown from the Forgotten Corner, dawn

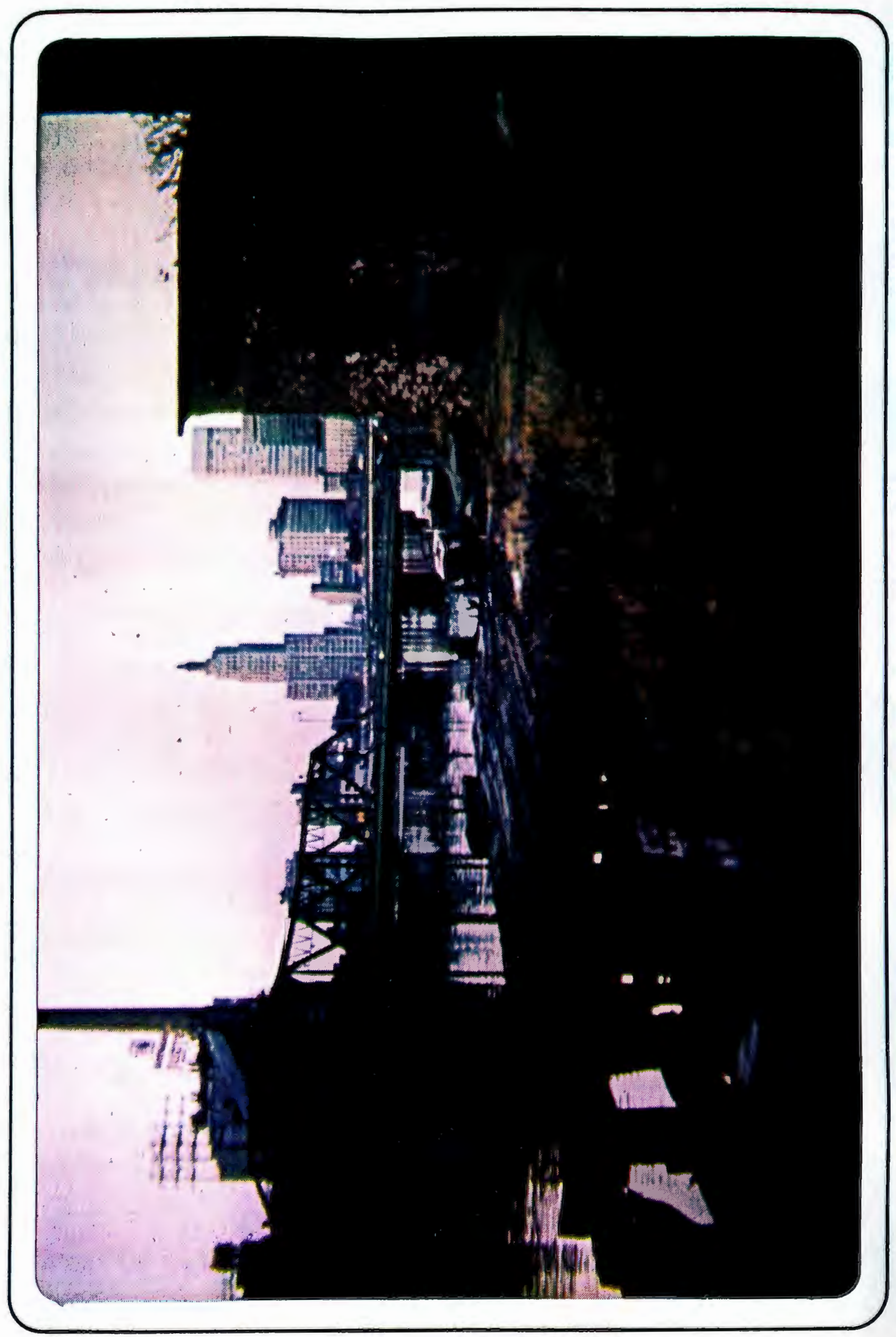


Problem Statement

\section{Context}

Downtown Providence and College Hill are significant physical focal points for future development within the City of Providence. Revitalization of Downtown Providence, stated by the Mayor as a primary goal of his administration, is a vital key to the future prosperity of the city and surrounding Standard Metropolitan Statistical Area. The Downtown area is a business-commercial center with unique problems, while College HiII reilects activities in historic preservation and higher education in an affluent residential neighborhood. Within five to ten minutes walk of Downtown and College Hill is a forgotten waterfont corner of the city, Fox Point. Fox Point is bounded by the Providence River on the west, Narragansett Bay on the south, India Point Park and the Seekonk River on the east and by I-195 and College Hill on the north. Fox Point is not to be confused with the residential neighborhood of the same name lying north of and completely separated by the I-195 corridor.

Problem

Providence has had in the past a role as the traditional center of urban activity within the state. Situated at the head of Narragansett Bay, its harbor once witressed an energ, a hustle and bustle, parallel to few harbors in New England. Today its once dynamic waterfront has greatly declined. The Providence waterfront has always meant a great deal to the development 
vitality and prosperity of the city, and in turn the vitality of the state's major urban core significantly mirrors the economic vitality of the region in which it lies. Hence revitalization of the Providence waterfront remains a vital element in the renewal of economic vitality to the city and region.

Fox Point is an unorganized assortment of various commercial and industrial enterprises on part of the urban waterfront. It. was once the home of various steamship lines that plied up and down the Bay and Iong Island Sound. Today there is no residential land use on the site. Fox Point is approximately 26 acres of waterfront property in a state of advanced blight: a forgotten corner.

Due to related environmental, social and economic factors, the present Fox Point land use appears to be outside the realm of a true market mechanism in that the highest and best potential uses of the land would seem to contradict the present downward development/land use trend.

Under the Mayor's encourage of revitalization, Providence has been progressing steadily toward a vital, thriving new city. The present administration is committed, along with a policy of revitalization and renewal of the Downtown and surrounding residential areas, to a revitalization of the Providence waterfront, long abandoned, abused and forgotten as a people place. Due to Fox Point's location on the Bay, its relationship to College Hill and Downtown, and its relative inadequate and uncomplimentary land use, it is apparent that the site offers 
figure 1

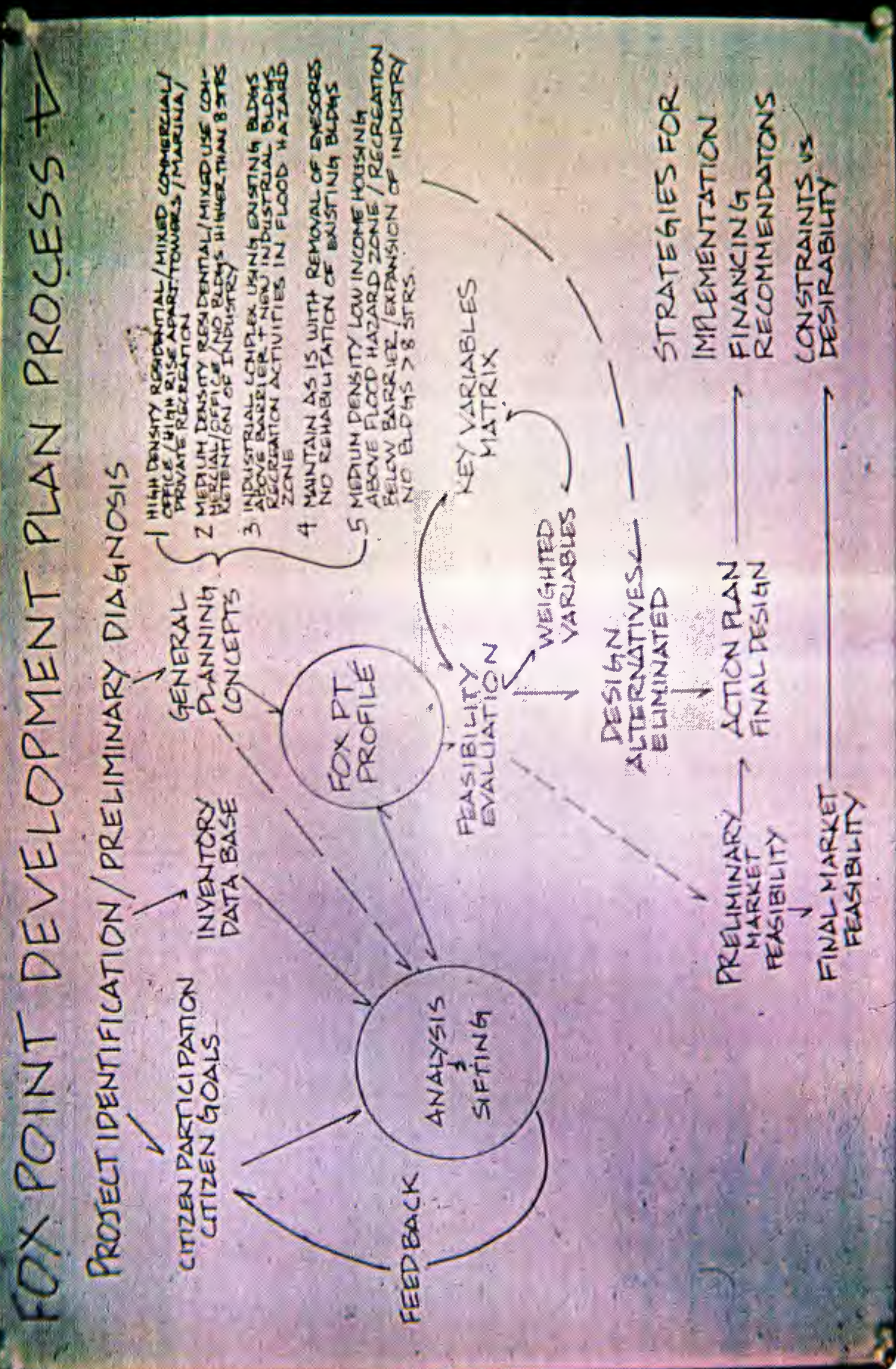


extraordinary opportunities for the development of a more meaningful people-oriented urban waterfront environment. The Fox Point site is physically part of the city of Providence and should enhance it in a social, economic and environmental sense. It is clear that for development of Fox Point to be meaningful, a comprehensive development plan for the site needs to be set forth and advocated. Just such a plan and tools for its advocacy are proposed in this Masters research project, as the culmination of a comprehensive package of environmental, social and economic considerations. In this project these considerations have determined an exciting, balanced and innovative direction for development of Fox Point.

Initial project identification and preliminary diagnosis of the Fox Point site arose from our FaII 1975 Studio III "Providence Waterfront" in which a plan was developed for the waterfront of Providence from just north of the municipal wharf to the Crawford Street Bridge and Fox Point.

\section{Me thodology/Process Assessment}

There are three major components to the realization of the Fox Point Development Plan generated by this project (Figure 1 ). These elements are (1) an Inventory Component; (2) an Analysis Component; and (3) a Design Component. In the incorporation of these components in a system or process through which the project would flow toward completion, it was necessary to fit each component together--one with the other-under a guiding philosophy. This guiding philosophy can best be expressed as 
a philosophy of practicality, the viewpoint of the developer, of the banker, of a future investor. It provided an underlying perspective in the evaluation of constraints and opportunities for development and in the review of design alternatives. Likewise, the final products of the project, an economic/market statement, a promotional slide-tape presentation and a scale model of the development design emphasize a close relationship between developer interest at Fox Point and the practical aspects of investment, marketability and return.

The Inventory Component of the project brings together environmental, social and economic data for the Fox Point site in preparation for an analysis of the existing status and direction of land use activities at Fox Point. Three major elements comprise the Inventory Component: (1) A consideration of the goals of the Fox Point neighborhood property owners and institutions in relation to the present and future development of the site; (2) An environmental, broad social and economic data base oriented specifically toward potential development at Fox Point; and (3) Five general planning concepts of land use relationships that could be applied or imposed on development at Fox Foint (Figure 1 ).

The major elements of the Inventory Component are later assimilated in the Analysis Component through a sifting process. Variables inventoried earlier are introduced and analyzed according to constraints and opportunities they present for future development at Fox Point. Through this process a Fox Point Profile is generated. This profile is essentially both a status 
report on a comprehensive set of variables affecting Fox Point land use and also a comprehensive evaluated set of constraints and opportunities for future development at Fox Point. The total represents information on a group of over twenty variables directly influencing potential development at Fox Point. Fresented in categories the factors studied are: Environmental

- Bedrock and surficial geology including a soil profile

- Topographical characteristics including patterns of drainage

- Watershed characteristics

- Flood plain delineation including status of Federal Flood Plain Insurance Program

- Terrestrial vegetation zones

- Marine and terrestrial wildlife habitat

- Existing and projected water quality

- Currents and tidal change (cycles) including tide levels

- Shoreline erosion problems

- Climate--macro and micro

- Visual analysis

- Noise pollution

- Air quality

Social

- Population characteristics including Fox Point residential community and the City of Providence

- Governmental goals including comprehensive plans and ordinances

- Citizen goals and attitudes including specific Fox Foint community goals 
- Landowners goals/institutional goals

- Transportation networks--bus linkage, vehicular limitations on site

- Present land use

- Historical land use including history of existing buildings

- Housing needs of the Fox Point community

- Community services including adequacy of police, schools, fire protection, sewerage, water, gas and electric

Economic

- Profile of existing employment and industrial viability of Fox Point at present/taxes accrued/work force

- Marketability/analysis of Downtown Providence

Through a feasibility evaluation which incorporates a Matrix Analysis (Figure 2 ) of key variables weighted appropriate to their influence on Fox Point development, planning concepts posited in the Inventory Component are eliminated-cancelled out as they become less meaningful for Fox Point development. This ilatrix Analysis is essentially a scorecard of constraints and opportunities (t and - ) of individual key variables juxtaposed to different planning concepts. It allows for a more objective selection of a planning concept for Fox Point development based upon a comprehensive site analysis.

Environmental and social key variables are presented here with a brief summary of their inherent, major developmental constraints and opportunities. Economic variables are presented separately in the Economic Statement. 


$$
\text { MATRIX ANALYSIS }
$$

figure 2

KEY VARIABLES / PLANNING CONCEPTS $(t,-)$ OPPORTINITIES, CONHTRAINTS TO DEVELOPMENT RANNING CONEERS:

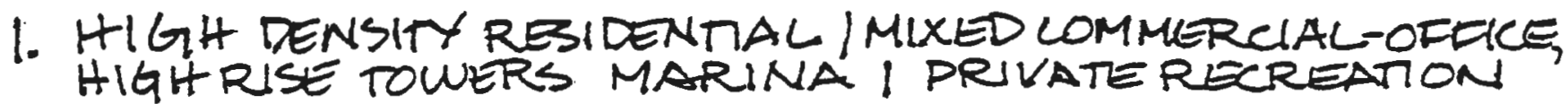

2. MEDUM DENSITY REBIDENTIAL I MIXED USE COMMERCIALOEEILE NO BUILDINGS HGHER THAN 8 STORIES

3 INDUSTRIAL COMRLER USING EXISTNG BLDGS ABOVE BARRLRR

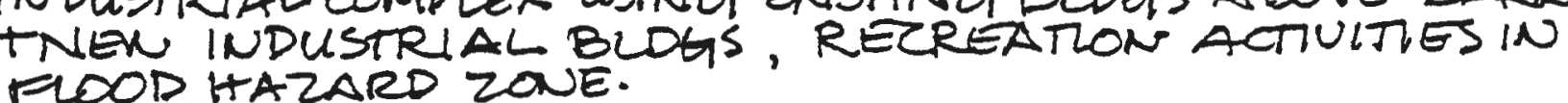

4 maintainas is Witti REMOVAL OFEYESORES. NO ReHAB OFERISING BUILDINGS

5 MEDUM DEUSITY LOWINCOME HOUSING ABOVE FLOD HAZARD ZONEI REREATN BEOW BARRIER
EXPANSION OF INDUSTRY NOBDGS
S STORIES

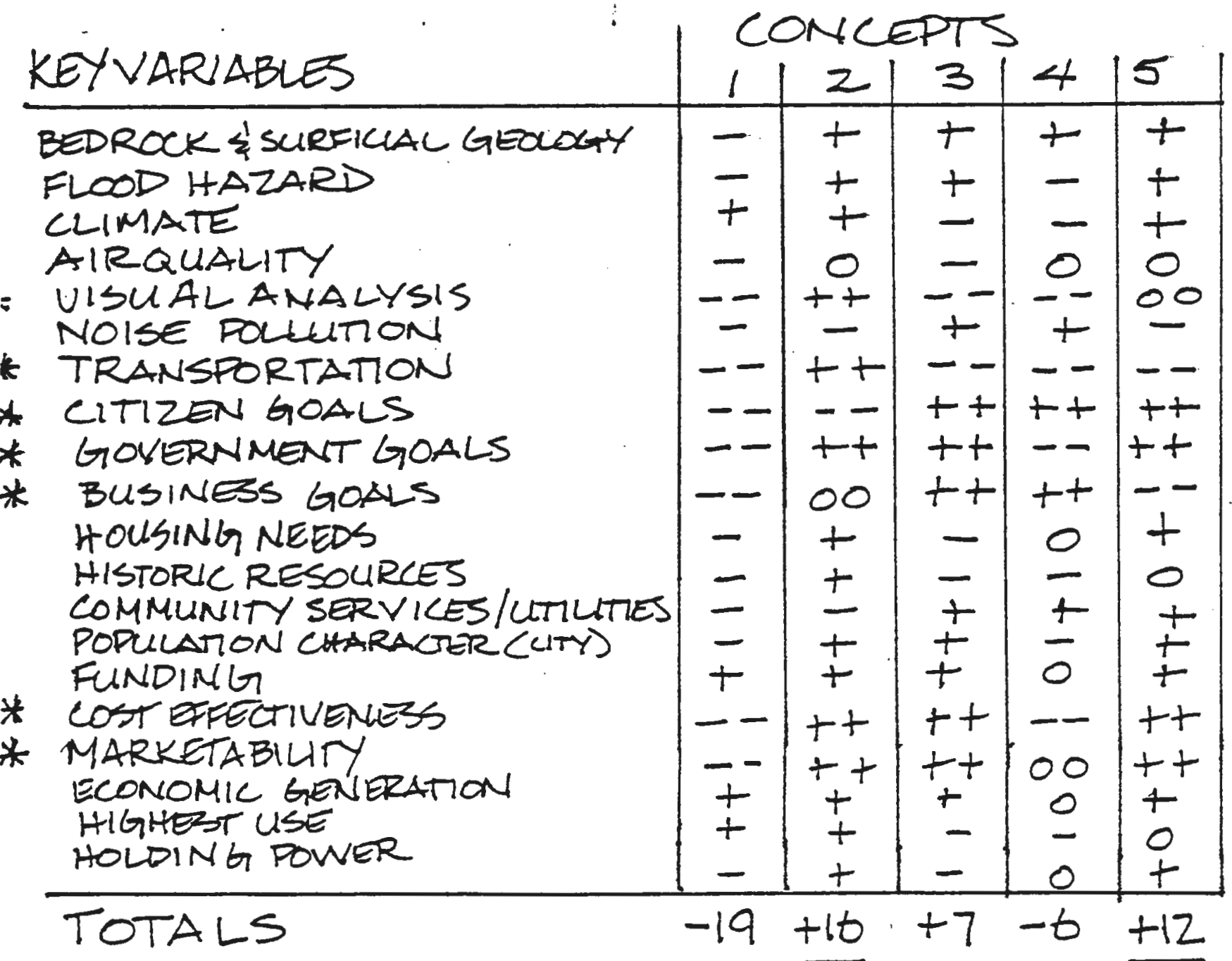


figure 3

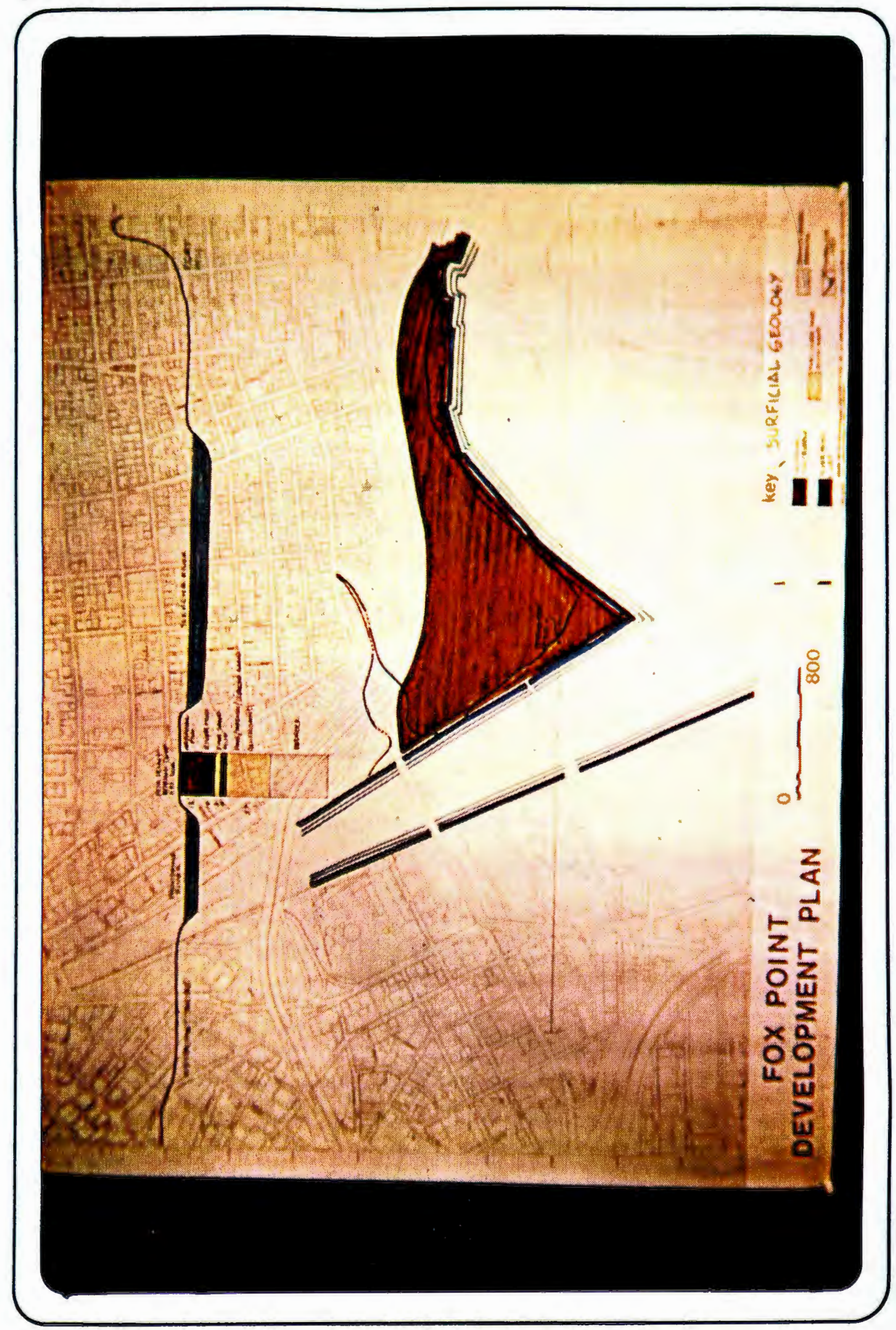


Bedrock-Surficial Geology (Figure3)

The site is generally built up of artificial fill and has been repeatedly altered by surface excavation in areas below the Fox Point Hurricane Barrier. The soil profile is composed of generally consolidated fill dating from the early to late 19th century. Fill could be composed of a mixture of stone (ruins) and other foreign matter. Soils are poor. Due to intensive land use activities the artificial fill is consolidated. Depth of fill ranges up to 18 feet (test scoring 78 , India Street). Pennsylvanian bedrock is located approximately 98 feet below the ground surface. Mud, sand and quicksand lie between artificial fill and the bedrock.

New construction greater than nine stories in height would necessitate the use of foundation pilings which in turn would increase construction costs significantly. Buildings under nine stories in height could be built in matt or spread foundations with significantly less cost.

(Sources: Wm. H. Bierschenk, Ground-Water Resources of the Providence Quadrangle, $R$. I., Rhode Island Geological Bulletin No. 10, 1959, Vitto Nacci, Prof. Civil Engineering, University of Rhode Island.) 
figure 4

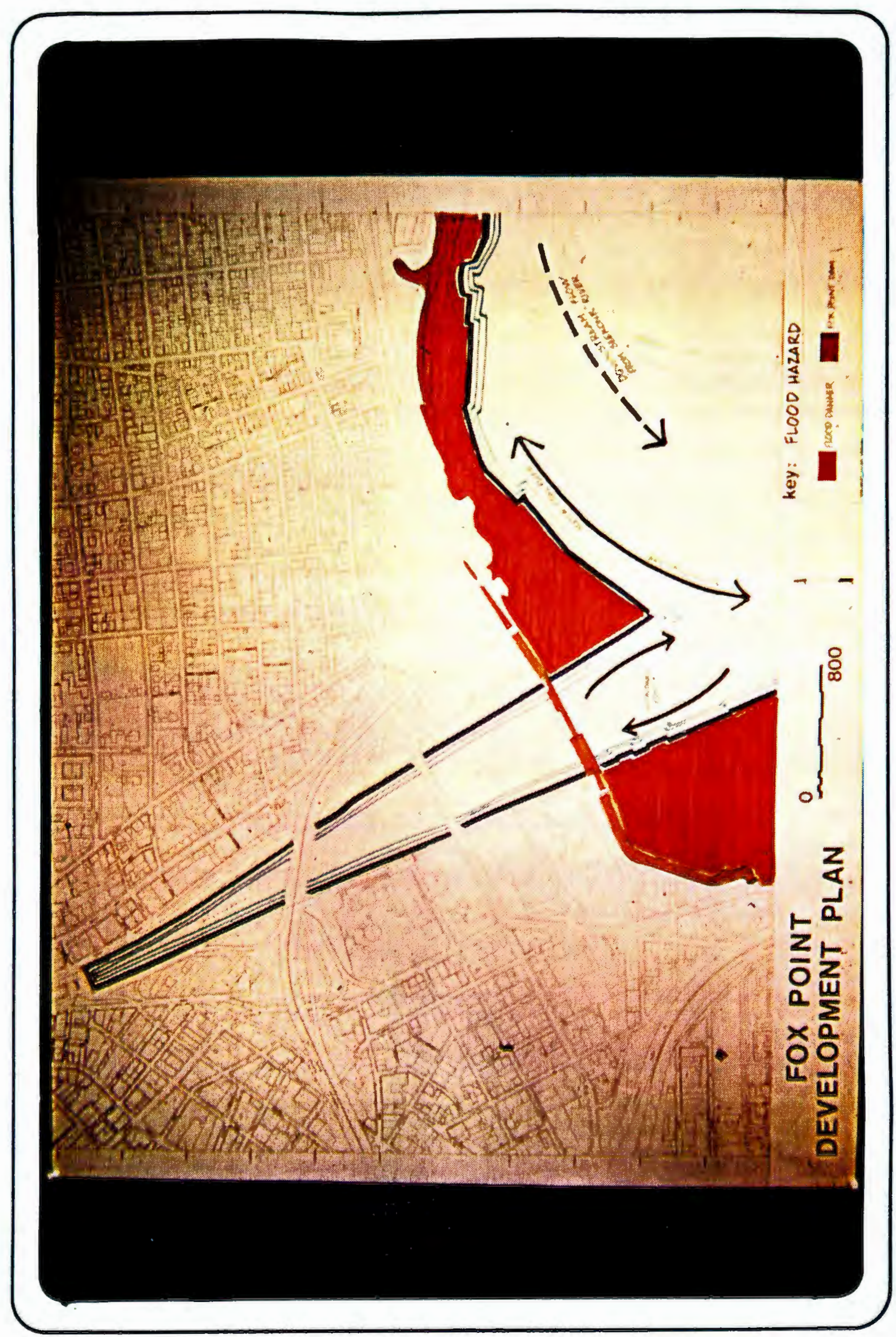


The Fox Point site lies partially within Flood Hazard Zone "A" which is "an area of special flood hazards without base flood elevations determined." The line of flood hazard demarktation lies at approximately the 16-foot topographic contour interval. This west to east line lies at the southem base of the Fox Point Hurricane Barrier. All existing land uses south of the Fox Point Hurricane Barrier, with few exceptions, are within the flood danger zone and therefore are subject to restrictions and guidelines of the Federal Flood Hazard Insurance Program. The Fox Point site is subject to periodic storm surge flooding caused by major cyclonic coastal storms. Major damage to the Providence waterfront was sustained in the major hurricanes of 1815, 1938 and 1934. The Fox Point Hurricane Barrier was built to protect upland property and especially Downtown Providence from storm surge and flood hazard. Special conditions of flood danger exist at Fox Point due to its location at the confluence of several major river systems at the head of Narragansett Bay.

New construction at Fox Point within flood danger zones is not encouraged. However, if construction methods in floodable first floors, elevated, floodproofed buildings or innovative site preparation is planned, federally-subsidized flood insurance is obtainable. Special consideration of flood danger in juxtaposition to property values must be resolved if new construction is planned within the present flood danger zone.

(Sources: Flood Department, American Universal Insurance Co., HUD Federal Insurance Administration, Flood Hazard Boundary Map H-04, revised JuIy $23,1976$. ) 


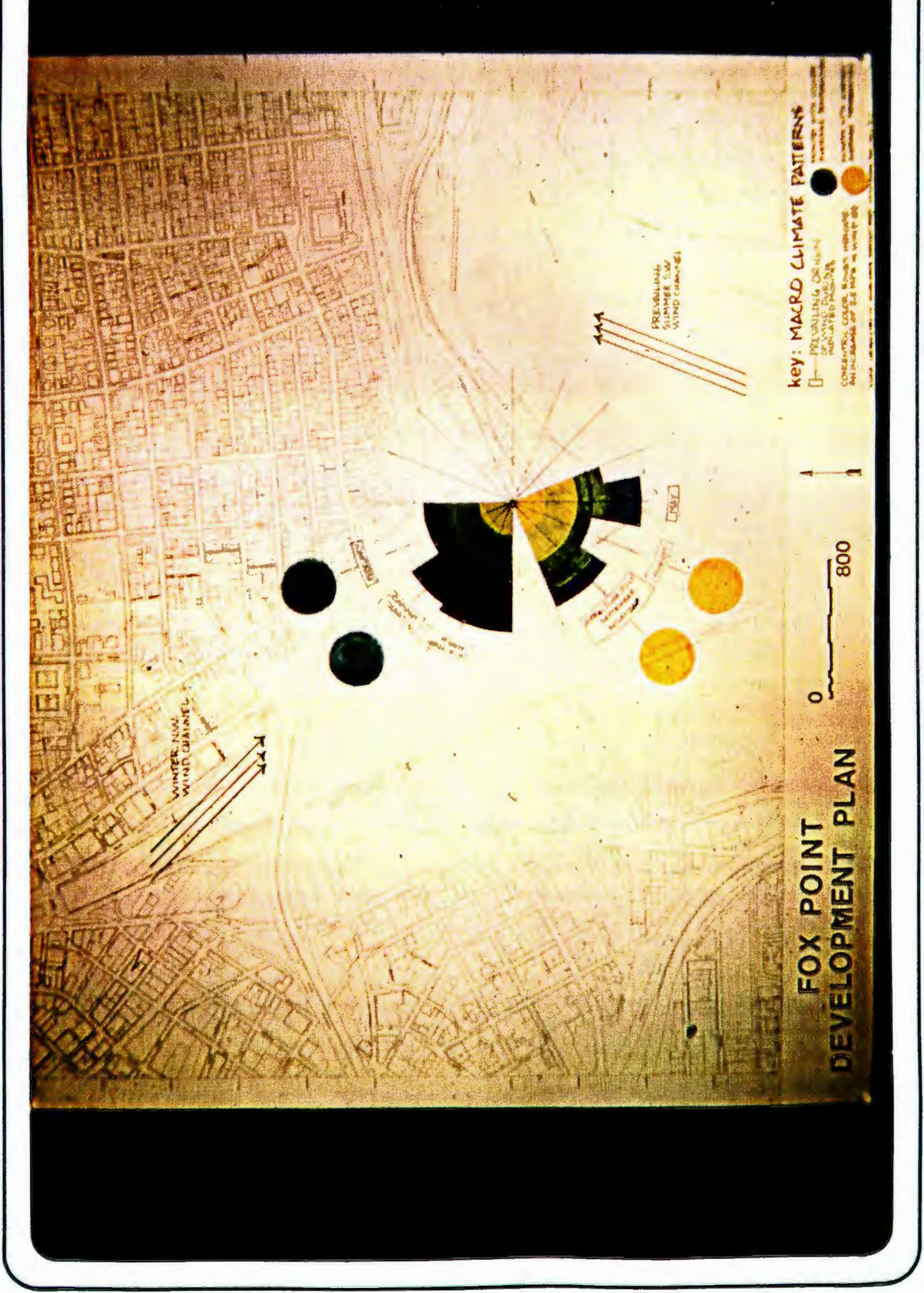


Weather conditions at Fox Point are not as consistent as conditions elsewhere on the Bay, particularly areas further south due to the movements of a "polar front" which shifts its location, traversing upper Narragansett Bay, periodically. This front mariss the boundary between cold dry polar air and warm moist tropical air. A shift further north can bring Frovidence rain instead of snow during winter storms. Iikewise, a shift further south in the front can bring far more severe winter weather to the Fox Point area than lower reaches of Narragansett Bay would experience. Summer weather is generaliy more stable. During sumer months the polar front moves further north. Summer city heatwaves are usually modified at Fox Point by southwest winds. These ocean breezes predominate during spring, summer and fall seasons, while winter months, particularly December and March, bring stronger wind pattems from the northwest.

The Fox Point site presents peculiar variations in micro climate due to large areas of low albedo, its predominent southerm exposure and Bay/harbor frontage. These modifying agents can significantly alter severe weather at the site. Chilling urban winter weather can be mild at Fox Point and likewise broiling summer urban heatwave weather can be modified by cool ocean breezes at the site.

In general, Fox Point weather is milder than weather in Downtown Frovidence or College Hill during all seasons. This is attractive for an urban residential environment.

(Source: Iee Pare \& Assoc. Environmental Assessment Report, Wilkes-Barre Pier, Providence, R.I., 1976, Kevin Lynch, Site Planning, MIT Press, Cambridge, 1974, field survey, Fal1, 1976.) 
figure 6

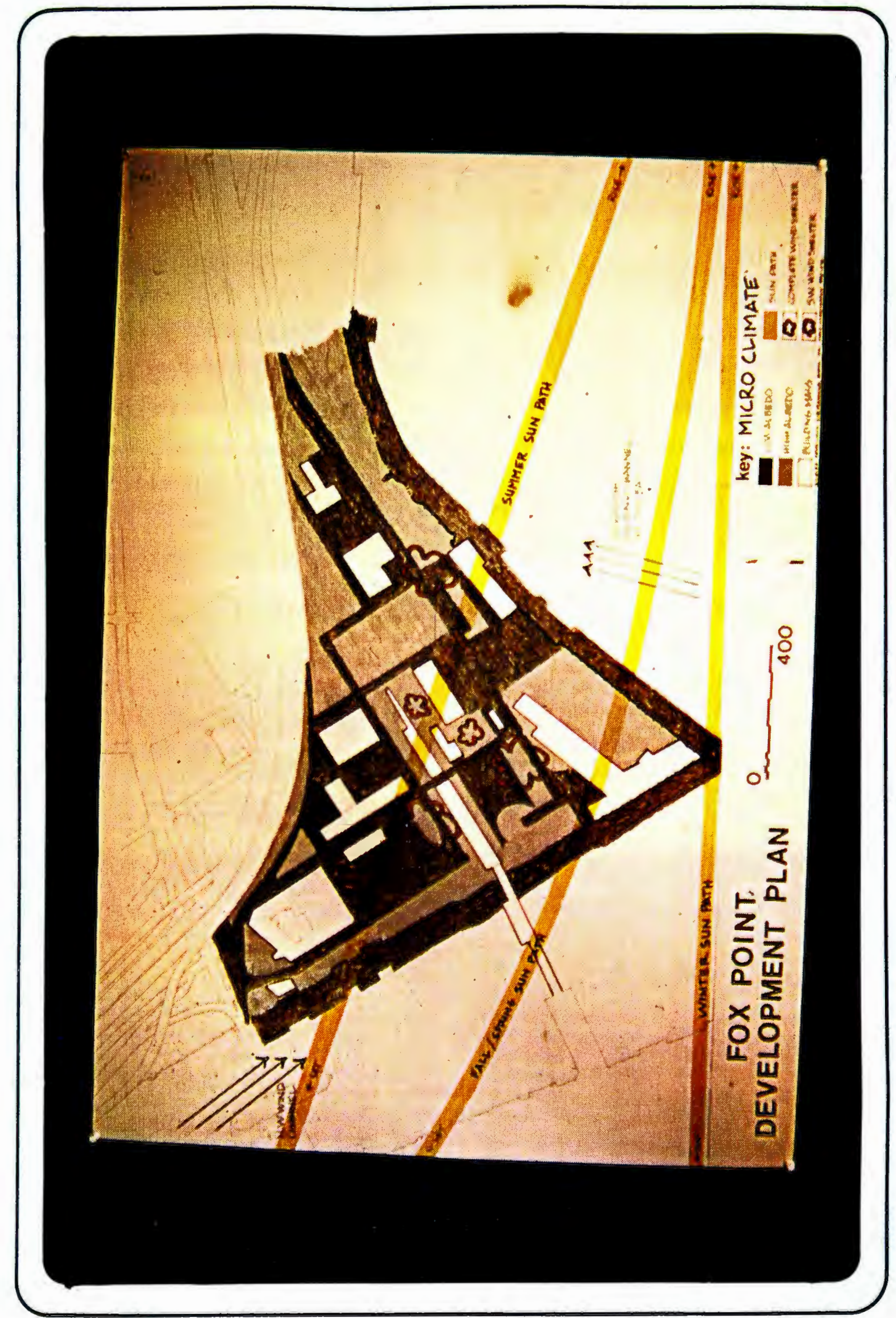




\section{Air Quality}

Rhode Island is presently meeting all federal and state air pollution standards. The major lists are for suspended particulates, sulfates, sulfur dioxide, nitrogen dioxide, carbon monoxide, and photochemical oxidents. Fox Point meets annual and 24-hour air pollution standards. However, marginally critical levels of particulate air poliution are created by I-195. Higher levels of air pollution are experienced in close proximity to the highway corridor.

Residential development should not be located in close proximity to I-195, particularly housing that would be subsidized with federal monies. It is clear, however, that Fox Point's location on the waterfront experiencing fresh Bay breezes modifies the incidence of air poliution considerably on the harbor side of the site. Pollutants generated by Narragansett Electric's power station are carried over the site to the north influencing pollution levels in College Hill and the East Side to a greater degree than Fox Point.

(Source: Thomas Noel, Div, Air Pollution Control, Rhode Island Health Department.) 
figure 7

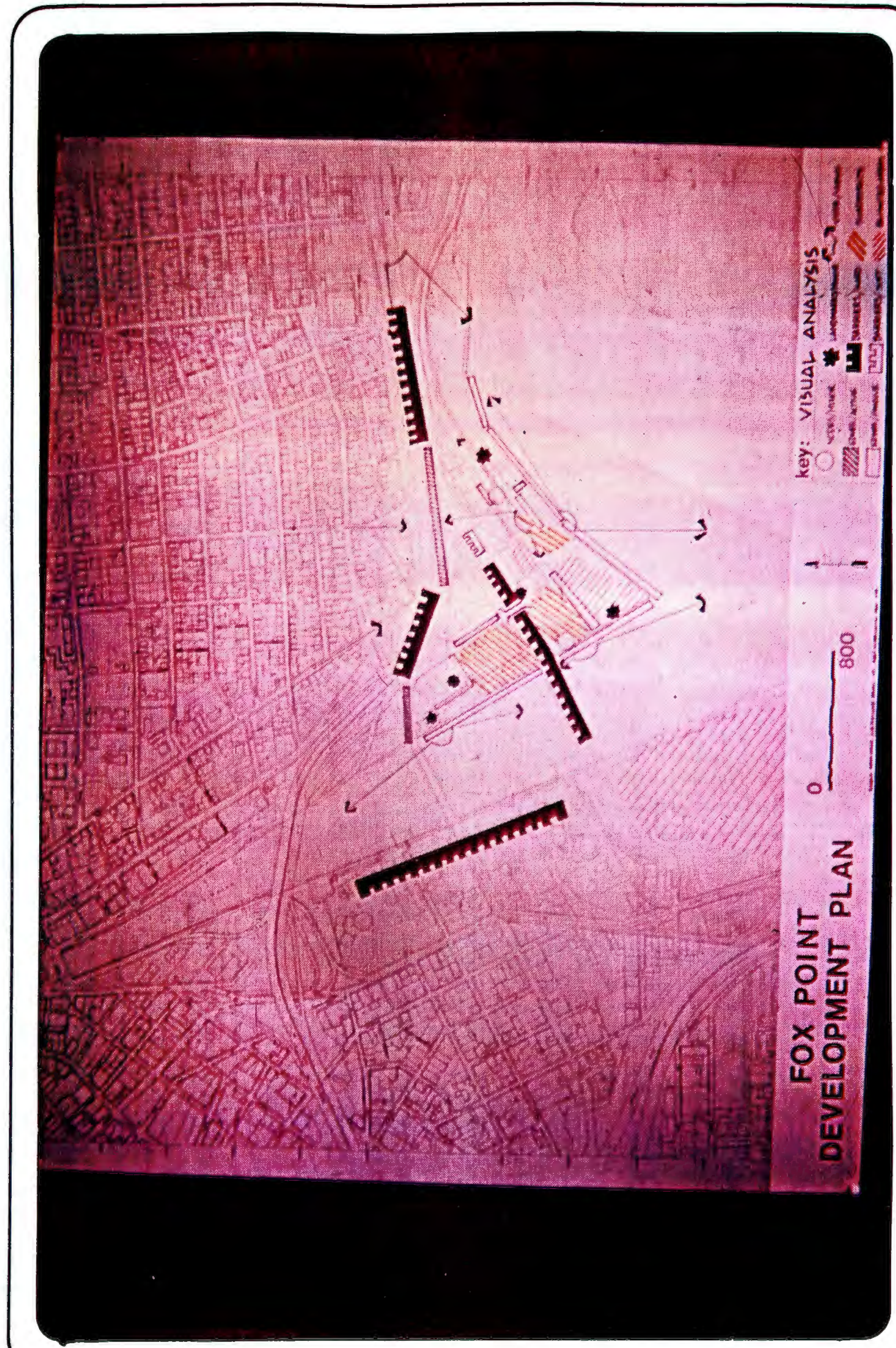


Visual Analysis/Aesthetic Conformity (Figure 7)

The visual appeal, in general, of the Fox Point site is not particularly satisfying even though there are visual surprises that give the location a great deal of character. Visual elements that detract from the aesthetic appeal of the site are manifested in the Fox Point Hurricane Barrier, I-195, particular blighted land uses, and the visual chaos of the Narragansett Electric Providence Power Plant. Elements that benefit the site are manifested in India Point Park, Providence Harbor, views of Downtown and College Hill and the display of lights at night, as well as several 19th century brick industrial buildings, cobblestones and granite curbings.

Fox Point does offer elements of visual character that can be capitalized on in new development. These advantages if incorporated in design can minimize the visual disadvantages of the site.

(Source: Kevin Iynch, Site Planning, MIT Press, Cambridge, 1974, field survey, Fali 1976.) 


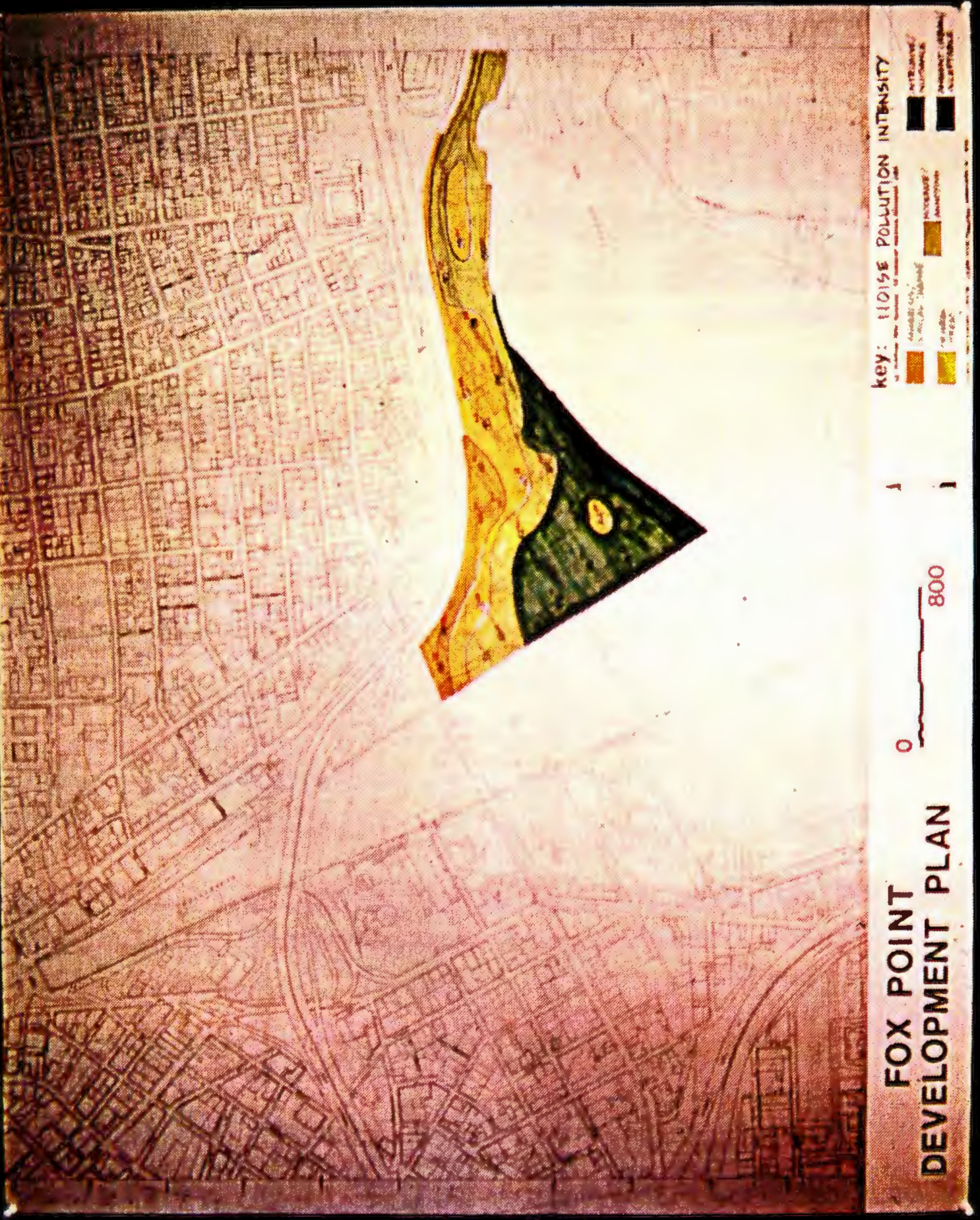




\section{Noise Pollution (Figure 8)}

Noise levels are high in areas with close proximity to the I-195 highway corridor. Here, noise levels range from $55 \mathrm{dBA}$ to $89 \mathrm{dBA}$ with a mean of approximately $62 \mathrm{dBA}$. Noise levels of over $90 \mathrm{dBA}$ are considered dangerous by federal standards. Ambient urban noise levels usually are in the 40-45 dBA range. The quietest locations within the Fox Point site are found along the southern bay/harbor front and between several buildings within this area. The noisiest locations within the site are in the vicinity of the northern front of the New England Butt Company at the intersections of point Street/wickenden Street with South Main and South water Street. An entrance ramp onto I-195 is also in this area.

Development at Fox Point if it is intended for uses other than industrial activity should be baffled in some way from excess I-195 noise. Residential housing units located near the highway corridor will need sufficient costly sound-proofing construction materials to eliminate the nuisance-dangerous levels of noise poliution present.

(Sources: Kevin Lynch, Site Planning; VIT Press, Cambridge, 1974, field survey, Fall, 1976.) 
figure 9

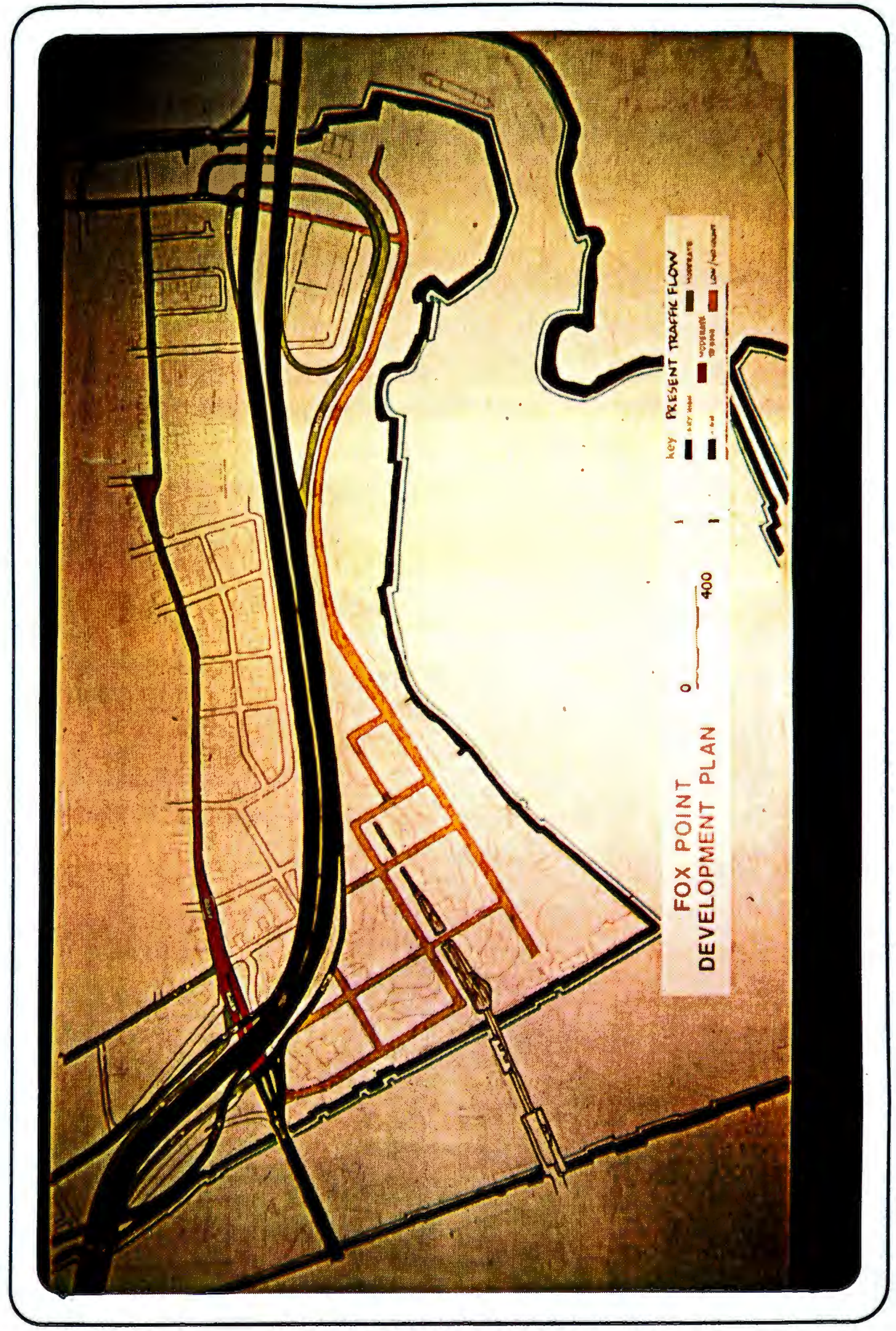


Existing Vehicular Transportation Network (Figure 9)

There are major vehicular access problems to the Fox Point site and India Point Park. Eliminations of I-195 on and off ramps in the vicinity of wickenden/Point Street Bridge cannot be justified and indeed would alter significantly, in an adverse nature, traffic flow and safety on the highway corridor and on Gano and Wickenden Streets. Traffic flow within the Fox Point site itself is light, but due to a grid network of street patterns, some of which are one-way only, through traffic flow to India Point Park can be confused. Mass transit (bus) routes do not exist in the Project area, but do exist along wickenden street and through the Fox Point neighborhood to the north.

Present road patterns and the ir use prevent direct unconfused entry to the Fox Foint site. In terms of I-195, significant changes to on and off ramps by additions to them or more especially elimination of them would burden to a detrimental degree already over-capacity Wickenden and Gano Streets. The simplest solution to the intersections of Foint street, South Water Street and Wickenden Street would probably seek to clean up the area and channel traffic more directly into the Fox Point site. Traffic flow within the site should be simplified by channeling traffic through the site more directly using parts of the existing grid street pattern. Persons using the site should be encouraged to park their cars as soon as possible in a facility. Miass transit (bus) linkage to surrounding neighborhoods and the Downtown should be brought through the site with stops at several locations.

(Sources: Traffic Engineer, City of Providence, Rhode Island. Department of Transportation, field survey, Fall, 1976, Rhode Island Public Transit Authority, Rhode Runner Bus Schedule, June, 1976.) 
Fox Point Citizen Attitudes and Goals

The following goals were set forth by individuals of the Fox Point Community Organization through a community-wide survey conducted by the organization in 1975 and several spokesmen for community interests:

\section{(1) Stabilization of neighborhood ethnic quality}
(A) Miaintenance of low and stabilized rent structure
(B) Confinement of Brown University and RISD students to housing on the neighborhood's northerm and western periphery
(c) Confinement of historic rehabilitation activities to northern and western peripheries
(D) Retention of waterfront land as part of the Fox Point community

(2) Lower crime rate/dissuade incidence of juvenile delinquency

(3) Better retail/commercial/entertainment facilities in Downtown or close-by neighborhoods

Stabilization of the Fox Point residential neighborhood, a goal recognized as important for the maintenance of Fox Point identity, is influenced by undesirable movement of population into the neighoorhood. In this particular instance, the immigration is of individuals from a higher income bracket than the inhabitants. The opportunity for these individuals, be they young professionals or university staff, to move into an equally appetizing new residential neighborhood in similar proximity to Downtown and College iill could alleviate the immigration pressure the Fox Point neighborhood is currently experiencing, helping to stabilize the character of the neighborhood. A new commercial/residential community at Fox Point would also dissuade delinquency and other crime currently experienced in the forgotten corner and India Point Park while at the same time offering the Fox Point neighborhood north of I-195 a better retail/commercial and entertainment center in very close proximity to their community. These benefits of development at Fox Point are counter-balanced by Fox Point citizen opposition to any new housing or commercial enterprise that creates a market outside of their financial reach, hence threatening community ties by attracting upper-income groups.

(Sources: Fox Point Community Organization, Department of Planning and Urban Development, City of Providence.) 
Government Goals

(1) Revitalization of Downtown Providence to create a more viable central business district;

(2) Renewal of valuable waterfront property long neglected by the city;

(3) Increase office space and attract corporate bodies to locate in the city;

(4) Promote Providence as a convention center;

(5) Renew city transportation networks;

(6) Promote historic preservation and rehabilitation within the city.

Development at Fox Point could be a catalyst for future urban waterfront renewal in line with administrative goals for revitalization of Downtown and the City of Providence as a whole.

(Sources: City of Providence, Office of the Mayor, Department of Planning and Urban Development, The Miayor's Office of Community Development.) 
In general, propertya $(\uparrow)$ consider redevelopment of the Fox point site as not a vital element in urban waterfront renewal: (2) a few owners would like to expand their financial interests in the area: and (3) they are concerned about vandalism to their property.

The Providence Center Committee formed under the auspices of. the Mayor and U R I CPAD - Urban Field Centar recommended the following goals as a consulting body:

(1) Continuing the cIear and visible City Hall leadership which is bringing about a change in attitude in private and public sectors in favor or revitalization throughout the eity;

(2) Improving the image of Downtown as a pleasant, safe, secure, active and well-functioning environment;

(3) Waring the development of Downtown a fiscal priority in both private and public sectors;

(4) Establishing the Downtown as a center for city, state and southeastem liew England regional activities;

(5) Restoring and oroadening the economic base of the city through:

(A) The creation of a number of job-producing activities in the Downtown area;

(B) Providing present Downtown employees with opportunities for expansion within the city and by attracting new investors by providing city services support;

(6) Providing a mix as well as a variety of activities in the Downtown area which is consistent with current trends rather than imposing different activities which may be counter-productive;

(7) Strengthening the following Downtown activities

(A) Private office space, government office space and specialty retail

(B) Educational service space, hotel accommodations and cultural entertainment space

(C) Residential space and recreational activities. 
While property owners are reluctant to invest individually or cooperatively in Fox Point development, institutional and governmental goals advocate renewal, revitalization rehabilitation. This advocacy is strong and persistant. Several key property owners, if shown the real potential of Fox Point development and if encouraged in a meaningful way by city government to proceed with investment in their holdings, could produce, together, a vital new waterfront community in the heart of the city that would greatly benefit city revitalization goals.

(Sources: Providence Center Council Report to the Mayor, November, 1976, interviews with Fox Point property owners, Fall, 1976.) 
The goals of the Housing Assistance Plan (HAPS) best summarize housing needs within the City of Providence. These goals ask for a rehabilitation of existing housing stock, increased supplies of new housing for low and low-moderate income groups including the elderly (a group that comprises an ever-increasing proportion of the demand for such housing) as well as for financial incentives to ensure the availability of funds for starting costs for all proposed housing developments consistent with the Housing Assistance Plan goals. An assumption can be made that the status of housing in Providence points to an indication that a large percentage of the housing stock in the city is not competitive with housing on the mariset in outlying suburban areas. This trend adds to the push/pull factors forcing residents to move out of the city to where they can find better housing. It is supported by high single/double vacancy and demolition rates of existing city housing.

There is an opportunity to encourage in Fox Point development, suosidized low-moderate income housing. New middle to upper-income housing could also be developed on the waterfront that would compete with attractions of suburban housing hence luring suburban migrants back to the city. Both opportunities are consistent with housing demands within the city: (Further discussion of real estate markets is presented in the Economic Statement.)

(Sources: City of Providence, Miayor's Office of Community Development, HAPS, City of Providence, Department of Planning and Urban Development.) 
figure 10

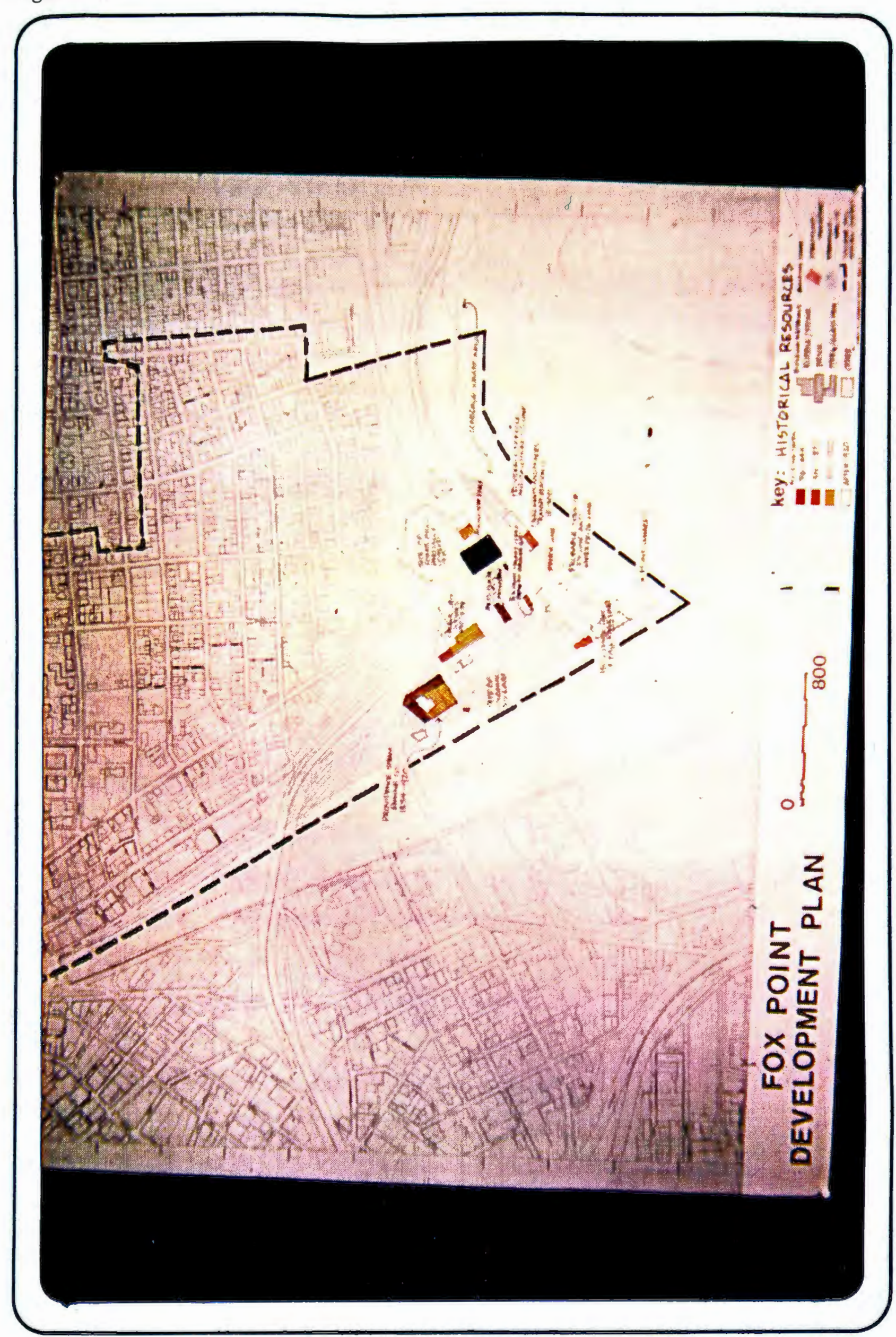


In summary, the Fox Foint site has rich and vital heritage as a major transportation mode and port facility for the $C_{i t y}$ of Providence until its decline after World War II. Significantly, it once served as a port of debarktation of Narragansett Bay excursion steamer boats and the famed Providence-New York-Fall River Iine Palace steamers. The buildings, most of which were built in the mid- to late l9th century, on the site were used primarily as support facilities for these transportation enterprises.

The Fox Point site lies within the jurisdiction of the "expanded" College Hill Historic District (not to be confused with the boundaries of the College Hill District Commission's jurisdiction which predominates on College Hill itself.) Buildings within this College Hill Historic District are placed on the National Register of Historic Places and therefore are bound by all regulations pertaining to the alteration of National Register properties if federal, state or local public assistance monies are used to alter their appearance.

Of the buildings located at present on the Fox Point site, only a few are of any historic or architectural significance. of these, three groups are of particular interest:

(1) The industrial manufacturing complex of the Providence Steam Engine Company (corner of South Viain StreetPoint Street-ifickenden Street-Pike Street-South Water Street), 1845, 1863-1869 period of expansion.

(2) The Fuller Iron Works buildings (two) (corner of Pike Street and South Main Street), 1869, 1910.

(3) The Hicks Boiler Works (South Wain Street), 1870.

Development at Fox Point can benefit from the incorporation of existing historic character with new construction. Federal monies are obtainable for rehabilitation of historic structures with historic districts.

(Sources: J.j. Cady, The Civic and Architectural Development of Providence, Rhode Island, 1957. The Historic American Engineering Record, The Rhode Island istorical Preservation Commission, Providence, Rhode Island, The Rhode Island Historical Society, Providence, Rhode Island, Mr. Gary Kulick, Slater inill inuseum, Fawtucket, Rhode Island, Dr. Patrick Malone, Slater Mill Museum, Pawtucket, Rhode Island.) 
figure 11

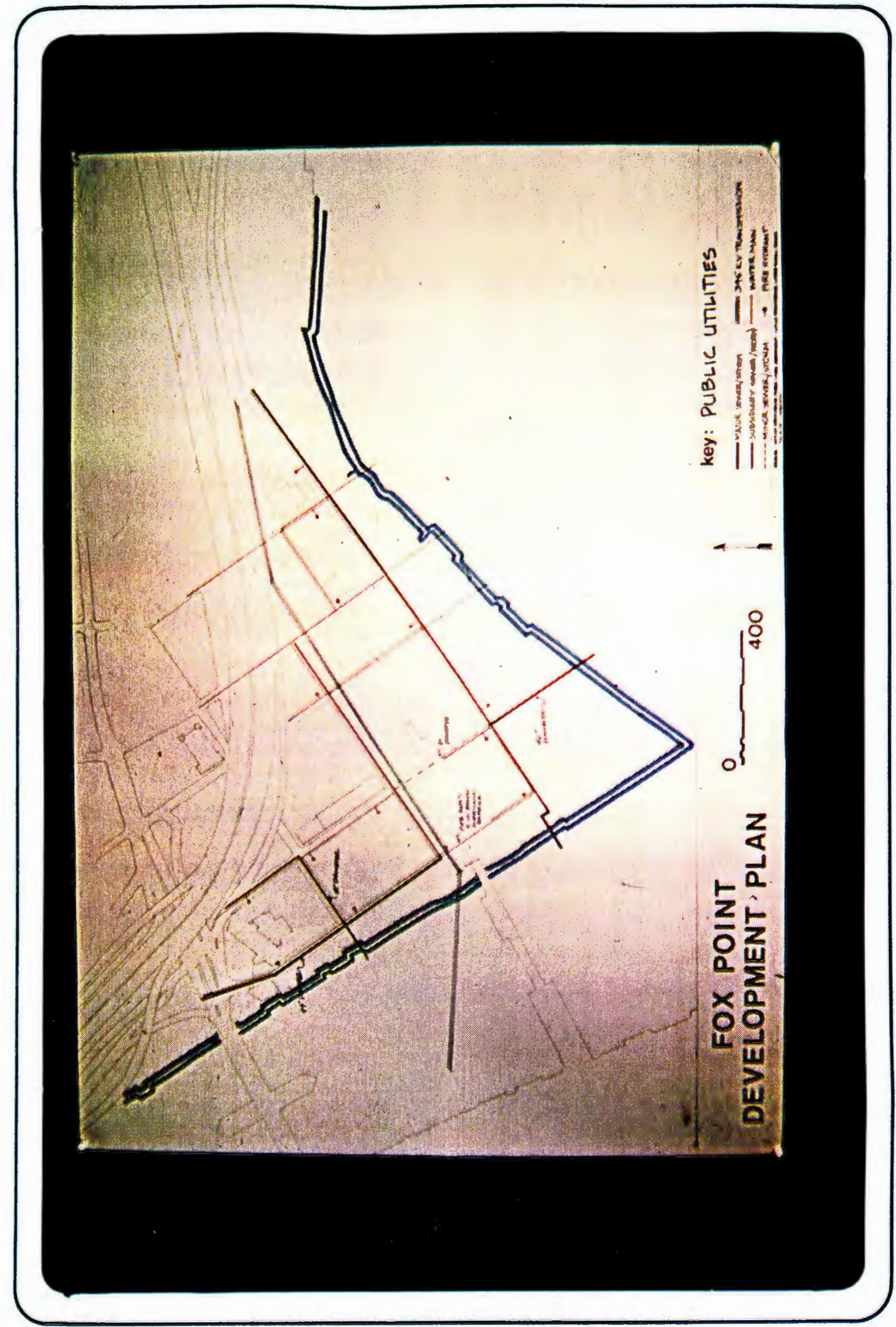


Fire Protection

Although there is only one fire station for the entire College Hill area, the Fox Point site is adequately serviced at present as an industrial area. Fire hydrants are located on every block throughout the site.

Police Protection

Due to an established high rate of vandalism and delinquency, the Fox Point site is under surveillance continually.

Schools

The Fox Pointementary School, located north of I-195, has not reached its capacity enroliment. There has been a decrease in student population city-wide.

Public Utilities

Gas, water and electric and sewer services already exist at Fox Point. These are incorporated into the existing street pattern. Sewerage city-wide has to be brought up to acceptable EPA standards in the near future. Improvements to the existing infrastructure at Fox Foint could be made concurrently with development.

Two major utility corridors effect present land use patterns at Fox Point. These are: (I) the Fox Point Hurricane Barrier; and (2) a $345 \mathrm{kv}$ transmission Iine linking the Providence Narragansett Electric Power Plant with the Brayton Point Power Plant to the east. These two utility corridors, adjacent to each other, bisect the site.

Fox Foint development would only require additional community services in one or two sectors (additional fire and police protection) with minimal cost.

(Sources: City of Providence, Fire Department, School Department, Police Department, ilater Supply Board, Public iorks Department, Narragansett Electric Company, Providence Gas Company.) 


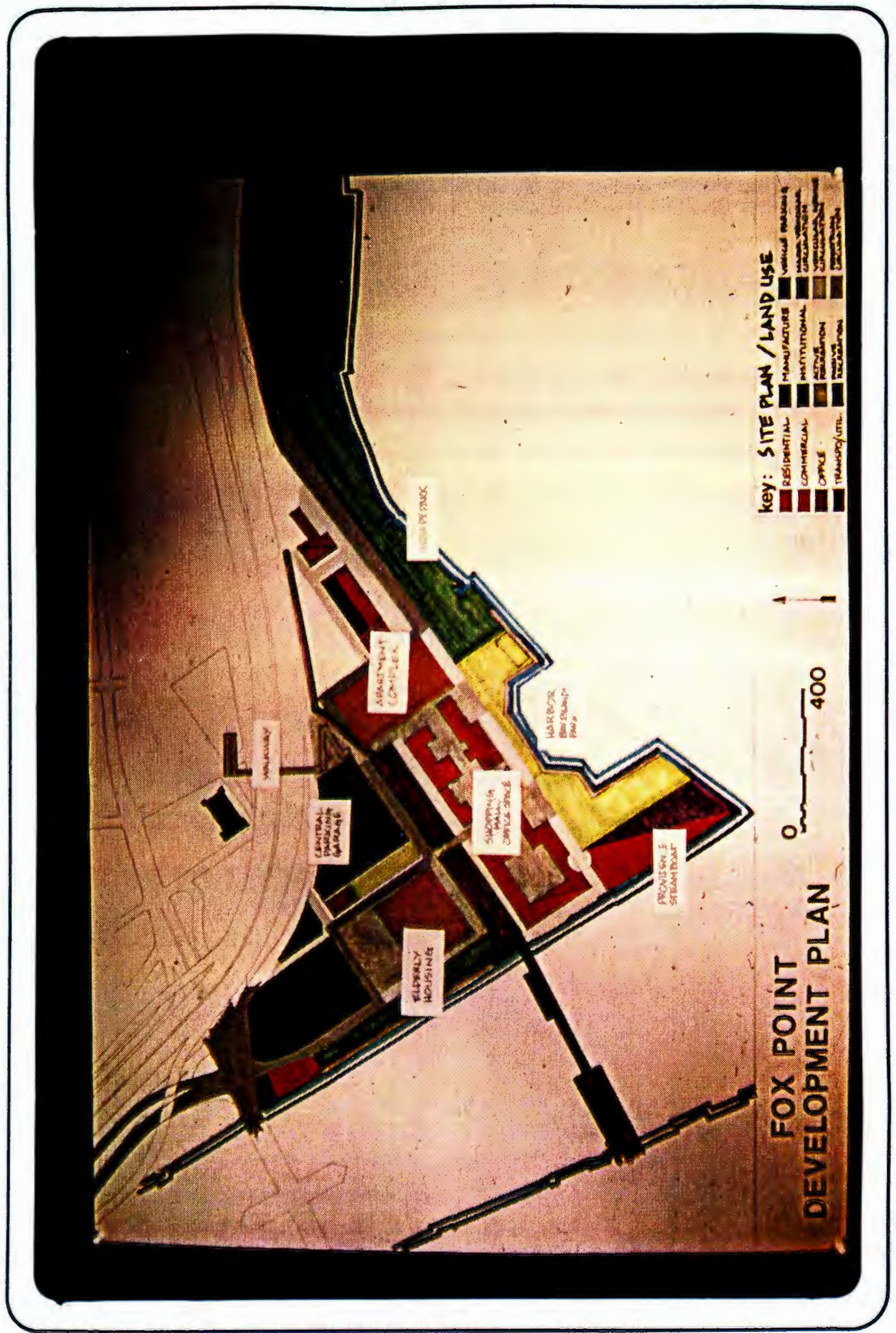


The next sequence in the process is the Design Component. Once the most appropriate land use mix was found for Fox Point development, a design concept could be set forth dealing with the specific constraints and opportunities of the key variables. Concurrently, a preliminary market feasibility test based on the chosen design tested the planning concept against economic requirements in tune with developer interest. Inherent in the whole process of developing a comprehensive site plan and design for Fox Point development is an approach in step with investment interests. This particular economic analysis of Fox Point development potentials is presented in the Economic Statement, a separate element of the product package.

\section{Design Summary}

The analysis of over twenty variables affecting the development of the Fox Point site has demonstrated that the combination of two principle land uses $((1)$ a mixed-use commercial and office complex with medium density residential units and (2) subsidized elderly housing with retention of viable industry and expansion of recreation facilities) into one package would make sense in terms of the optimum use of Fox Point land. This combination would also meet the recognized potential of renewal of the Providence waterfront for the greater enjoyment of the puolic and for the support of progressive revitalization of the city.

The Fox Point Development Plan calls for a mixed-use Planned Unit Development (PUD) (Figure 12). Elements of the 


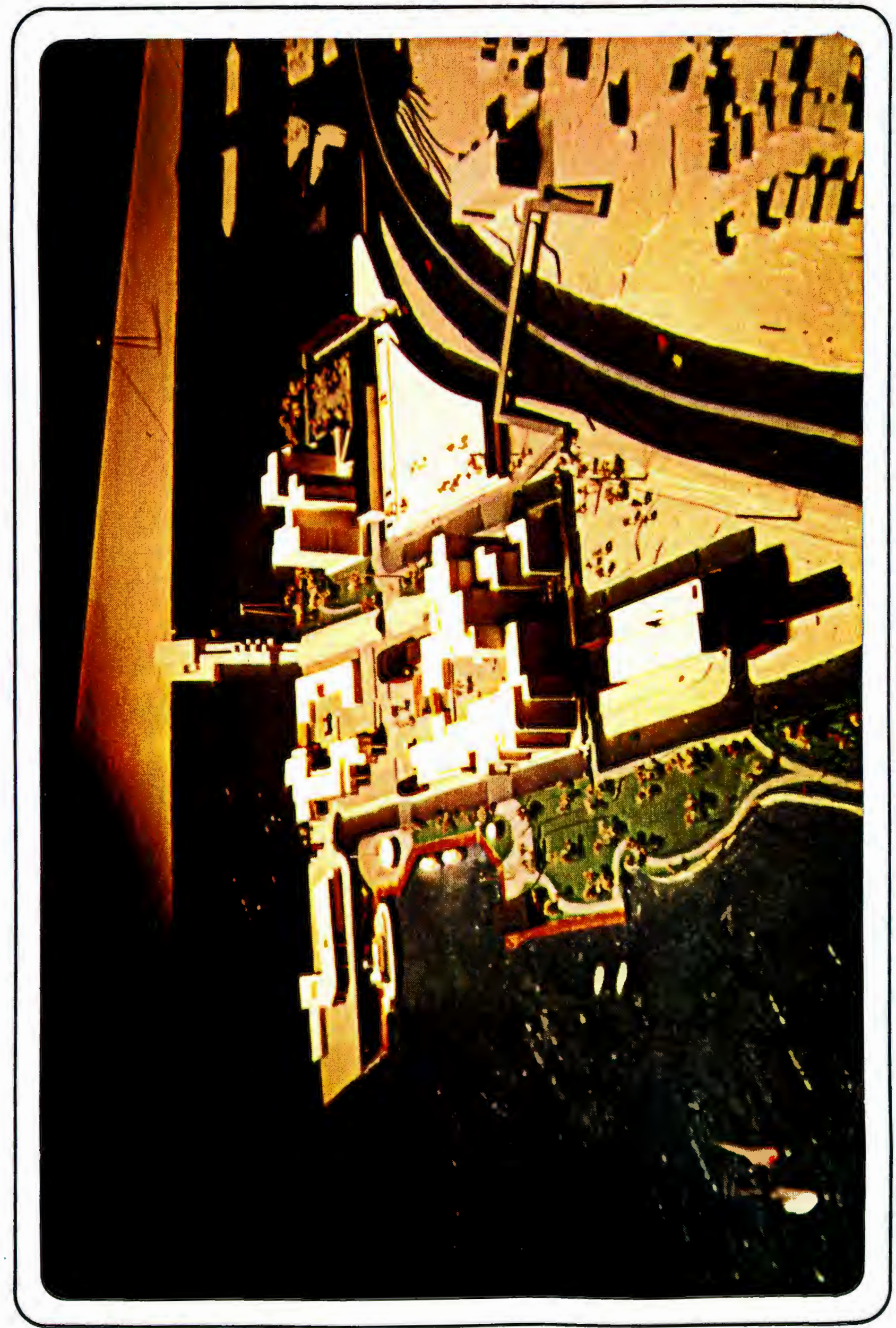


design, which can be better visualized viewing the model (Figure 13) and slide-tape presentation, include commercial space for small speciality shops (boutique and possible marine-related) and character restaurants (preferably marine-related), office space for service and corporate enterprises as well as for existing on-site businesses (marine-related enterprises could be encouraged to locate offices on the waterfront--shipping agents, etc.). middle- to upper-income housing for urban professionals and their families in close proximity to active and passive waterfront recreation, subsidized elderly housing in a sheltered zone adjacent to activity centers but not within the activity zones, a major and a minor parking facility to eliminate auto traffic congestion, and a proliferation of pedestrian precincts principally in a multi-level plaza allowing people access to the waterfront. These major elements of the plan are related to a major economic generator at the site. This is an excavated artificial harbor and new port facility for the Providence. terminus of the proposed Bay Islands Fark System, and the existing Providence-ivewport-Block $k_{A}$ ferlery system. Elements of this transportation system will operate throughout the year with peak tourist and recreational traffic in spring, summer and fall seasons.

Further, the design elements are incorporated into the existing environmental, social and economic fabric of the Fox Point site in a manner that is in tune with constraints and opportunities posed by bedrock-surficial geology, Flood plain hazard, climate, noise pollution, air pollution, transportation 
linkages and community goals. Design elements are proposed in a manner that enhance existing 19th century industrial architecture, ameliorate visual impacts of I-195 and the Fox Point Hurricane Barrier, share the ambience of India Point Park, while concurrently creating a separate new waterfront community.

An important element of the concept is its consistency of architectural design and detail. It is a philosophy to which development of the forgotten cormer should adhere to, if an investment in Fox Point is to be successful. Indeed, construction materials should emphasize and reinforce the flavor; a nostalgia; of the Age of Steam, of Victorian industrial architecture, of the era of the famous Fall River Iine, of wooden wharfs, iron, coal, tar, creosote, aged raw brick, granite curbing, and cobblestoned streets. These images, if reinforced in new construction, will recapture the character of a once prosperous Fox Point.

\section{Conclusion}

The Fox Point Development Plan is based on comprehensive analysis and its design proposes a transformation of a forgotten waterfront corner of the City of Providence to an economically vital catalyst for continued revitalization of the Providence waterfront. 
FOX POINT DEVELOPMENT PLAN

ECONOMIC STATEMENT 
The Iong-range goal of revitalization is to attract new investment into the neighborhood in the form of upgraded businesses, expanded store mir and product Iines, imaginative reuse of older buildings, and other forms of new development.

The process is comprehensive, cooperative and sequential. It is comprehensive as it recognizes that neighborhood viability inrolves a bost of factors and that the causes of decay must be attacked simultaneously. The process is cooperative. While neighbortood comercial revitalization starts with the businessman, it must have the support of the city and the comunity. While enphasizing that the private sector takes the primary responsibility and leadersbip for economic development and investment, it $F$ lews the city in a Ioveraging role, particularly in creating the pre-conditions for such private investment.

\section{Practicing Planner June, 1976 Article by \\ Benjamin Goldstein Chairman, National Ur- ban. Development Ser- vices Corp.}

Fox Point, the forgotten comer, was once an active, ewationing, and integral pert of the Providence waterfront. over the last forty years, this area has fallen into neglect and decay. One of the main precepts of this study has been to return people and vitality to the waterfront area. To accompish this end it is necessary to attract private interests to invest in the area's revitalization. To lend support to such a substantial private undertaking, state and local gotermment should aid in developing meaningrul public policy and augment development with relerant infastructure and support iaciIities.

To encourase this leval of private and jublic investment, 
economic trends and demands in Providence and near the Fox Point site would have to demonstrate reasonable prossures to cause investment and plan development.

A study of present economic conditions in rrovidence ensued which indicated housing pressures for different income groups, needs for commercial and office space development, and areas for expansion of service in the city. Although the Fox Point site is a separate community unto itself, it was deemed that any developable area in Providence would have to respond to market needs of the city as a whole. Conceptually the Fox Point site was linked to recent business development in the adjacent South Main Street area and would serve as a natural terminal point in opposition to development at Randel Square. Initially, a data search of other city projects shed. little light on current economic demands in Providence. The most current report, "Interface", demonstrated an immediate need of 100,000 square feet of office space per year over the next ten years. Office space seems to be the major need of the city due to expansion of service and government employment. This statistic was also verified by the "Union Station Rehabilitation Report."

Little additional current data was available to indicate other landuse needs for the city. The Providence Housing Authority was questioned in regard to immediate housing needs. It was shown that one major need is reflective in the long waiting list for elderly housing. A telephone survey of the major housing stmuctures in Providence concerning occupancy rates also confirmed thatbesides elderly housing, additional middle and upper income housing might be a strong possibility. Corroboration of these trends was sought through contact with 
several different sources including Textron (a major business), Gilbane (large development company), Gladstones (financial consultants), and major real estate companies. After this research process, several dominant recurring market demands surfaced as inmediate potentials for the city.

Market Demand for Providence

1) Inmediate demand for elderly housing.

2) Immediate capability to develop 90 - 100 tuxury housing units.

3) Office space demand of 100,000 square feet per year for the next ten years.

4) Commercial expansion capabilities in local neighborhoods in Providence.

Research involving the development of Providence as a convention center indicated also that the city has need for expansion of its night activity and active and passive recreation.

This research was to serve as one major basis for determining landuse mix in our Fox Point site plan.

It was also deemed necessary to verify real estate activity on the Bast Side of Providence in order to substantiate the health of the housing market for various income groups. The East Side sales area was chosen as indicative of a relevant housing market area due to its socio-economic mixture. The annual comparative data in the "Statewide Multiple Listing Service" manual was referred to for years 1974 and 1975 for such information. 
Real Estate Transactions for the East Side-= Area 12

1974

Total unit sales-- 126

$\%$ sales of total activity-- $69 \%$

Average selling price-- $\$ 43,159$

\% of listing price received-- 90\%

Average sales time of houses sold-- 64 days

Average listing not sold-- $\$ 62,169$

1975

Total unit sales-- 117

No. units under $\$ 25,000--26$

$\%$ of sales under $\$ 25,000--22 \%$

No. units $\$ 25,000-\$ 29,999--15$

to of sales $\$ 25,000-\$ 29,999-\div 13 \%$

No. units $\$ 30,000-\$ 39,999--14$

$\%$ of sales $\psi 30,000-\$ 39,999--12 \%$

No, units $\$ 40,000-\$ 49,999--26$

$\%$ of sales $\$ 40,000-\% 49,999--22 \%$

No. units $\$ 50,000-\$ 59,999--12$

$\%$ of sales $\$ 50,000-\$ 59,999--10 \%$

No. units $\varphi 60,000$ and over-- 24

$\%$ of sales over $\$ 60,000-21 \%$ 
Area 12 in Statewide Real Estate Ranking (Out of 45 areas) Total units sold-- 4 th best in state

Value of sales-- $\$ 2,382,790$ (9th in state)

Average listing-- 451,322 (4th in state)

Average selling-- $\$ 47,655$ (4th in state)

Average selling time-- 81 days (15th lowest)

to of list price received-- 73\%

Median salo-- 430,250 (11th in state)

Average listing not sold-- $\$ 52,315$

Rank in total sales action-- 12th in state

These tables help confirm that a strong market exists for middre and upper income housing. Clearly the East Side is a special case; however, the point is to demonstrate that a viable middle and upper income housing market does exist near the Fox Point site. Fox Point could offer many different and yet similar amenities as an urban waterfront community. Such an activity would draw people back into Providence and possibly siphon off some of the potential housing market on the East Side.

Combining the perspectives of the real estate data and the marketability information, economic trends become more apparent. Fox Point, the forgotten comer, is a separate community from already established communities. The interstate highway aids in distinguishing it as a separate entity.

Develiopment of a proper design mix for the waterfront site aids in creating an exciting and active new comunity. The new residential areas on the waterfront for middle- and upper-income groups with attrative adjacent commercial and office space uses will provide a new vigor near the central city. This new development would draw people for its activity, re- 
creation, waterfront, and residential potential.

Presently Fox Point is a twenty-six acre site with a total land value of $\$ \mathbf{\$ 1}, 595,762$. City taxes collect annually $\$ 71,842.87$

It is recommended that development of the site be undertaken by private interest, possibly from an association of several present land owners. Rehabilitation would affect about one half the site, while the remaining half would be subject to intensive new development.

The following maps and tables specify exactly which property is to be acquired and where new buildings and activities will be located. The tables indicate clearly the development potential for the Fox Point site.

Cost and income figures were derived from contact with real estate consultants, a major local developer, and contact with the University of Rhode Island's Civil Engineering Department.

The following maps and tables more precisely indicate the development potentials at Fox Point.

Miap 1-- Parcel map.

Map 2-- Building location map.

Table 1-- Characteristics of landuse disposition.

Table 2-- Construction staging.

Table 3-- Construction costs.

Table 4-- Total additional costs.

Table 5-- Income.

Table 6-- Comparative cost to income statement. 


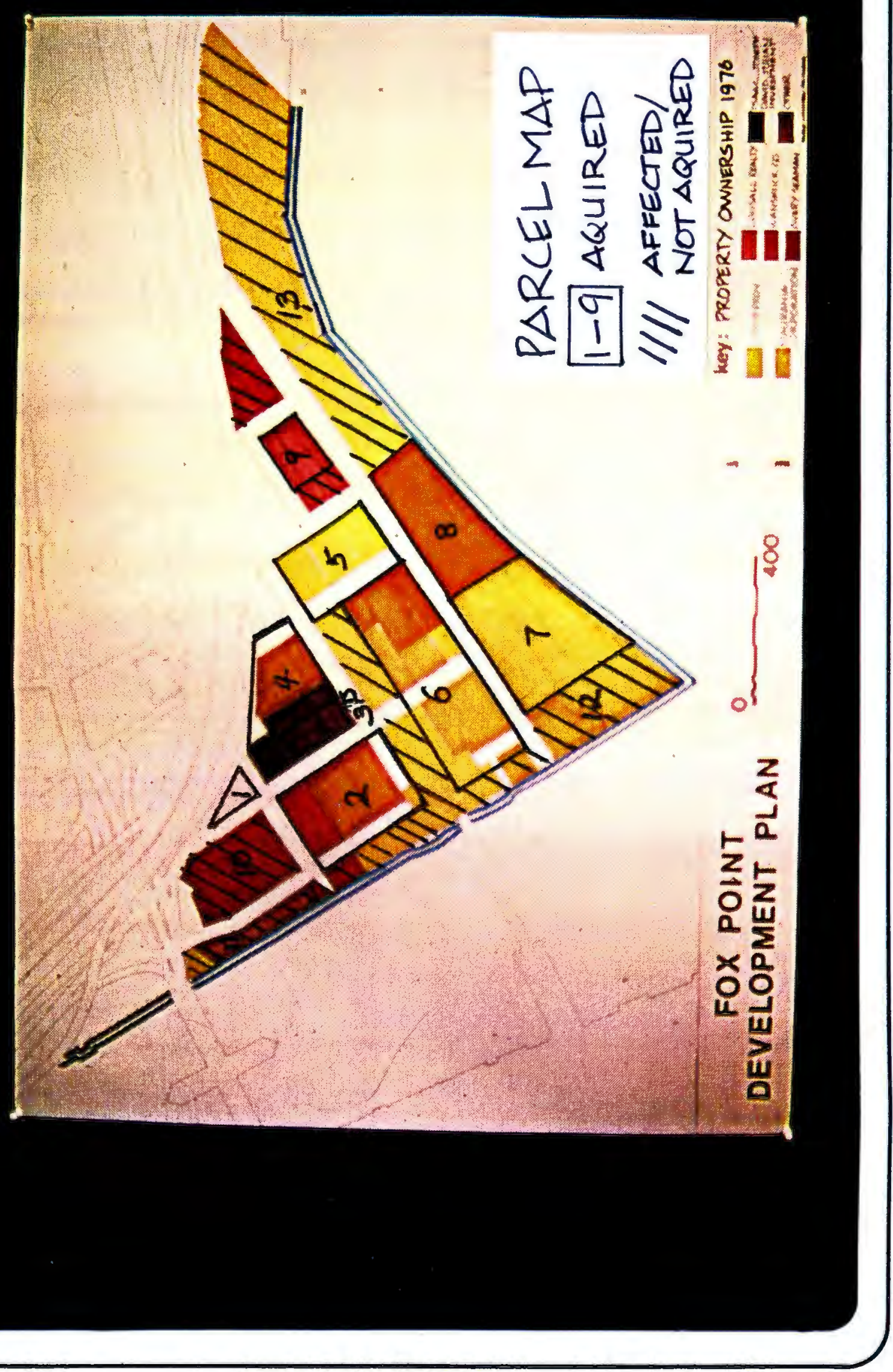




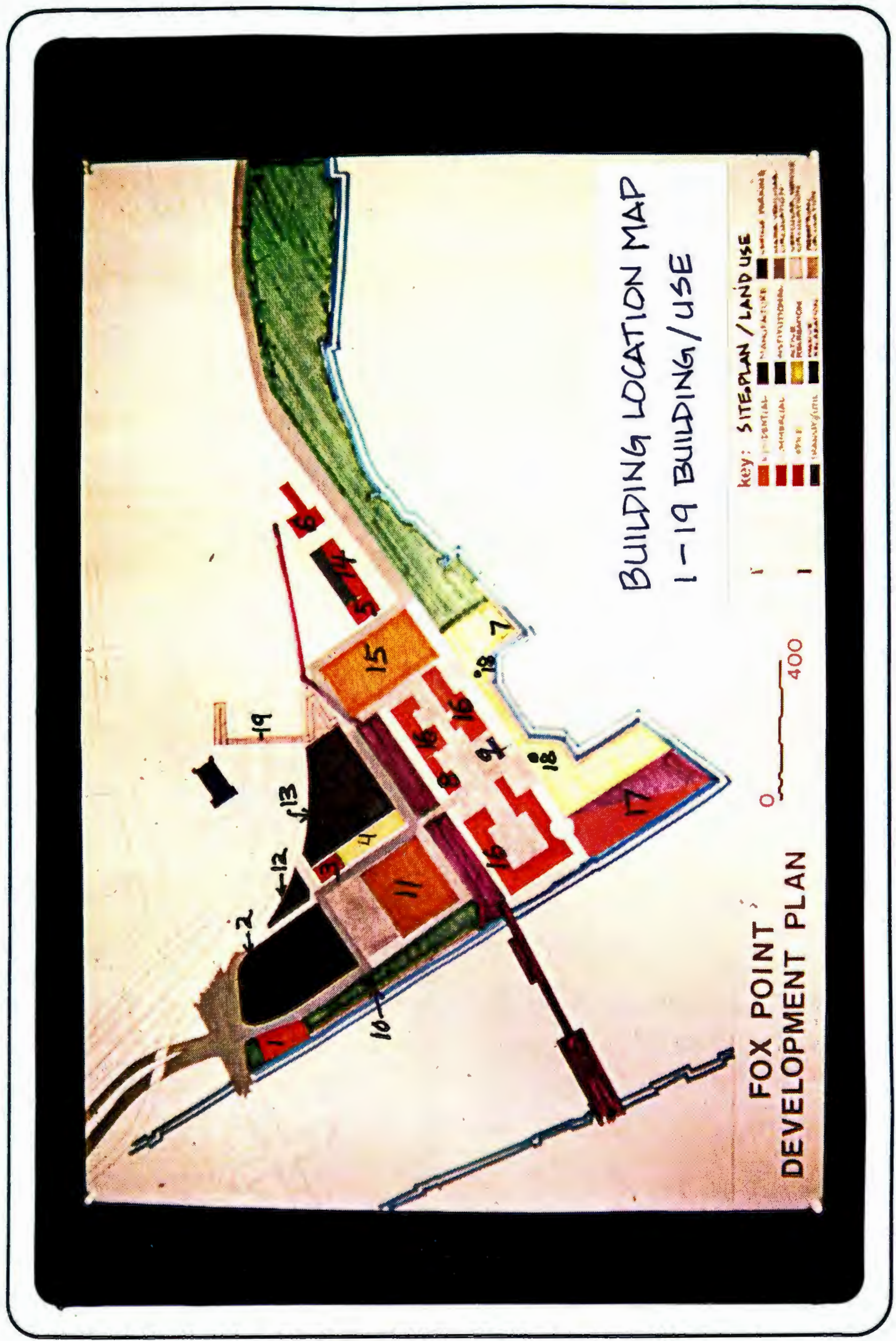


TABLE 1

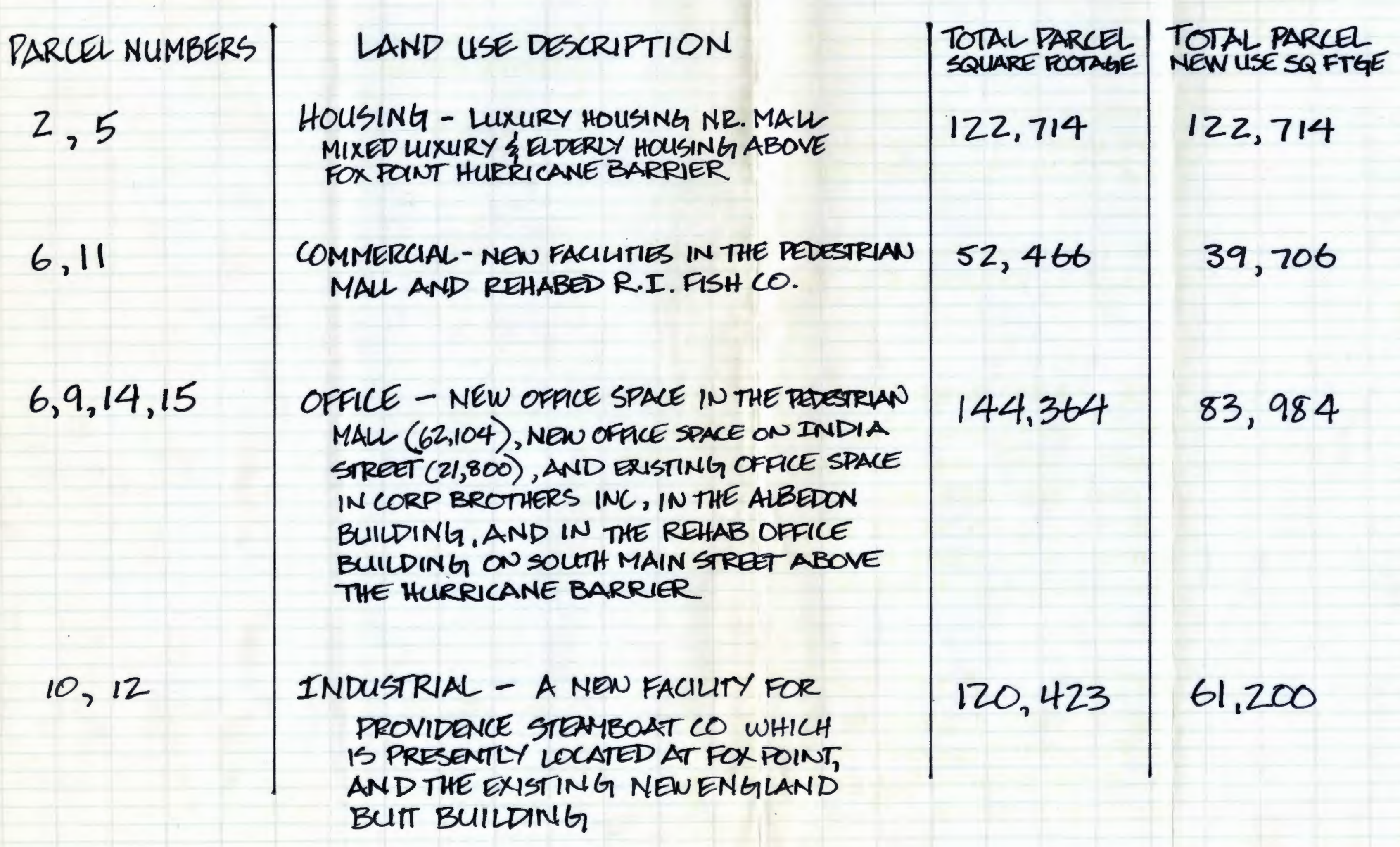


TABLE I (CONT.) CHARACTERISTICS OF DISPOSITION PARCELS

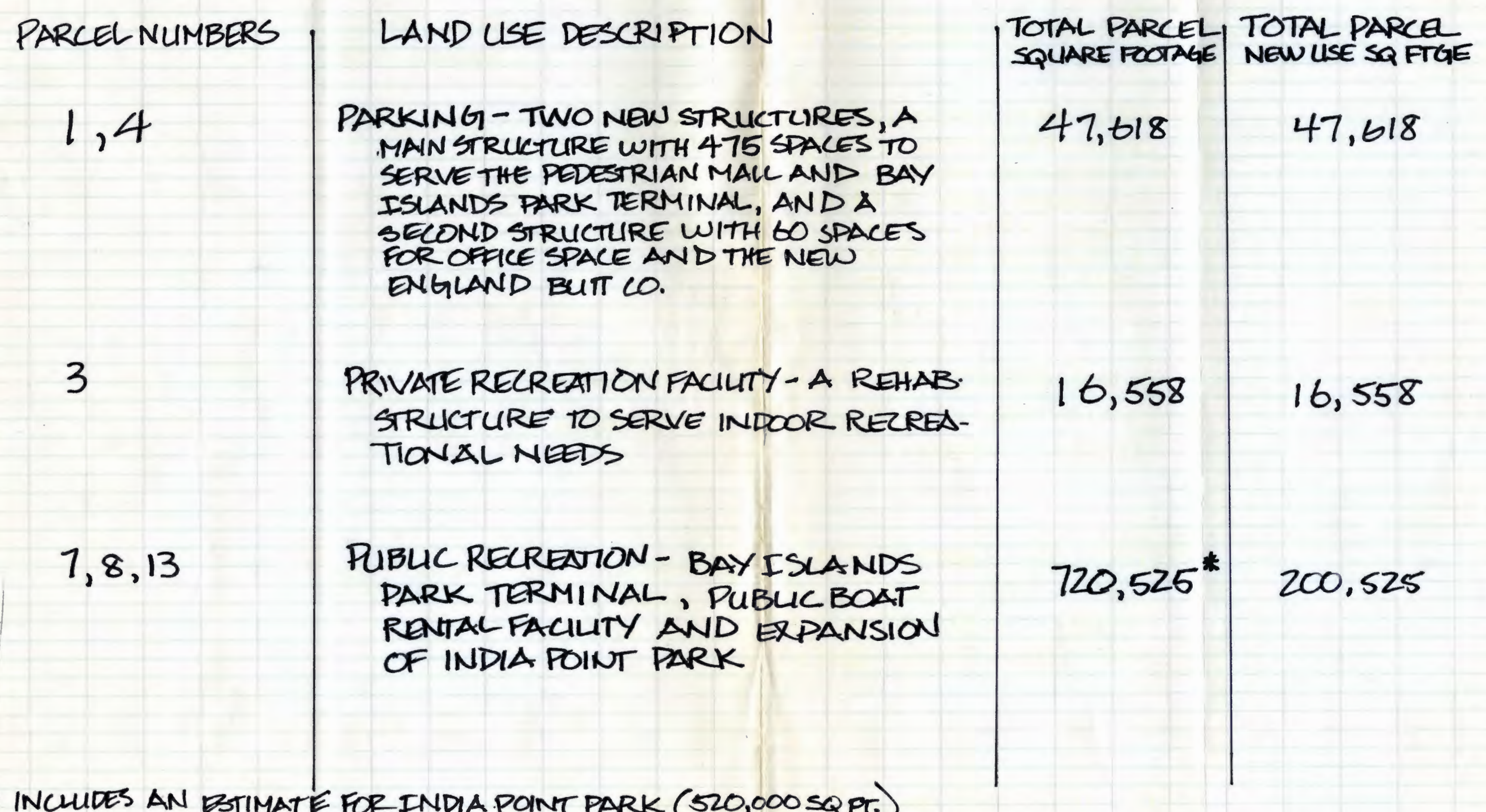

* includes an bromate for india point park (520,000 sq pt.) SOURCE: CITY OF PROVIDENCE, PLAT MAPS / TAX ASSESSOR'S MAPS 


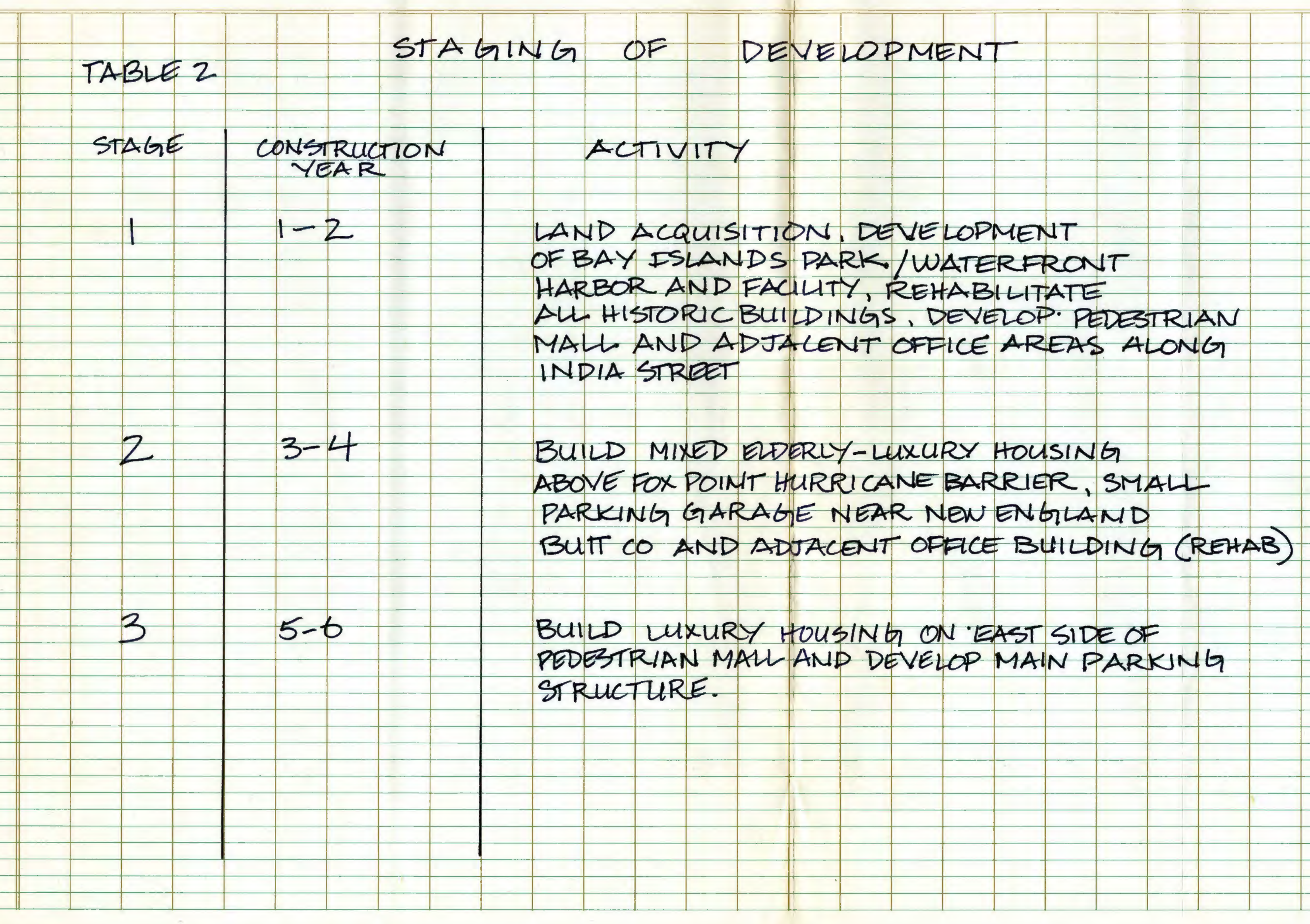


TABLE 3 TOTAL PRIVATE AND PUBLIC INVESTMENT COSTS BY CONSTRUCTION STAGE (Z YR INCREMENTS)

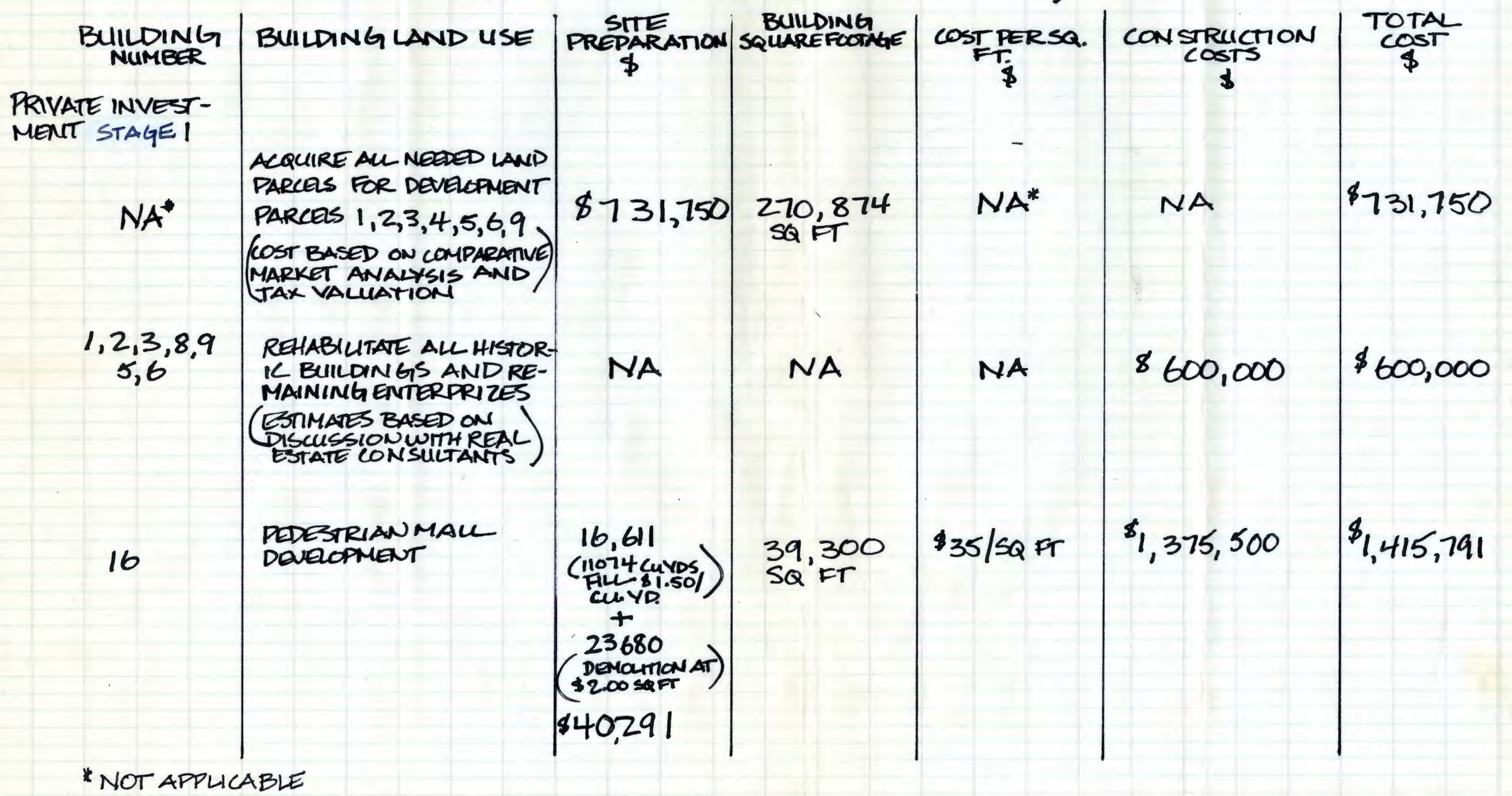


TABLE 3 (CONT.) TOTAL PRIVATE AND PUBIC INVESTMENT COSTS BY CONSTRUCTION STAGE (YR INCREMENTS)

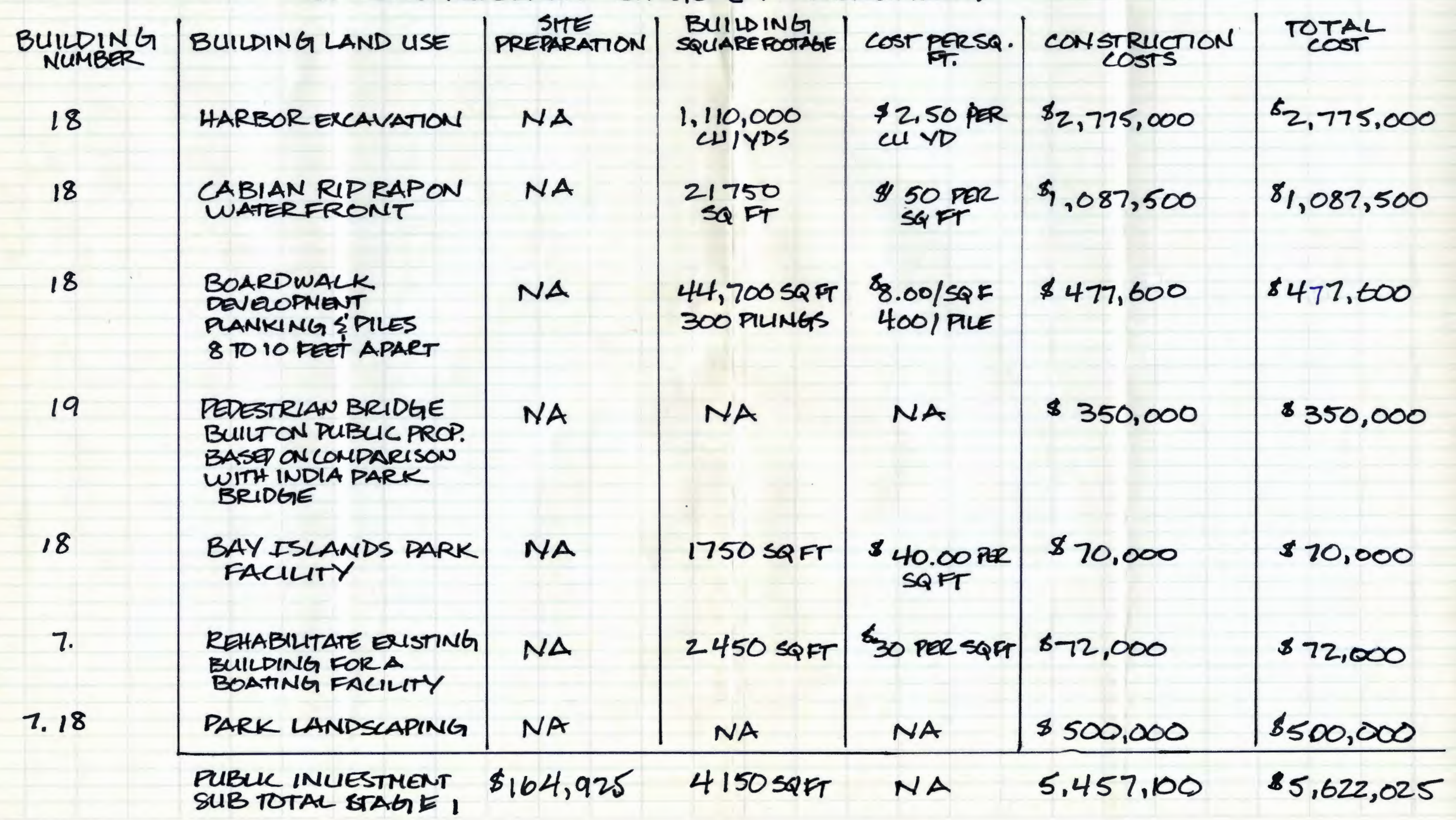


TABLE 3 (CONT.) TOTAL PRIVATE AND PUBLIC IN VESTMENT COSTS

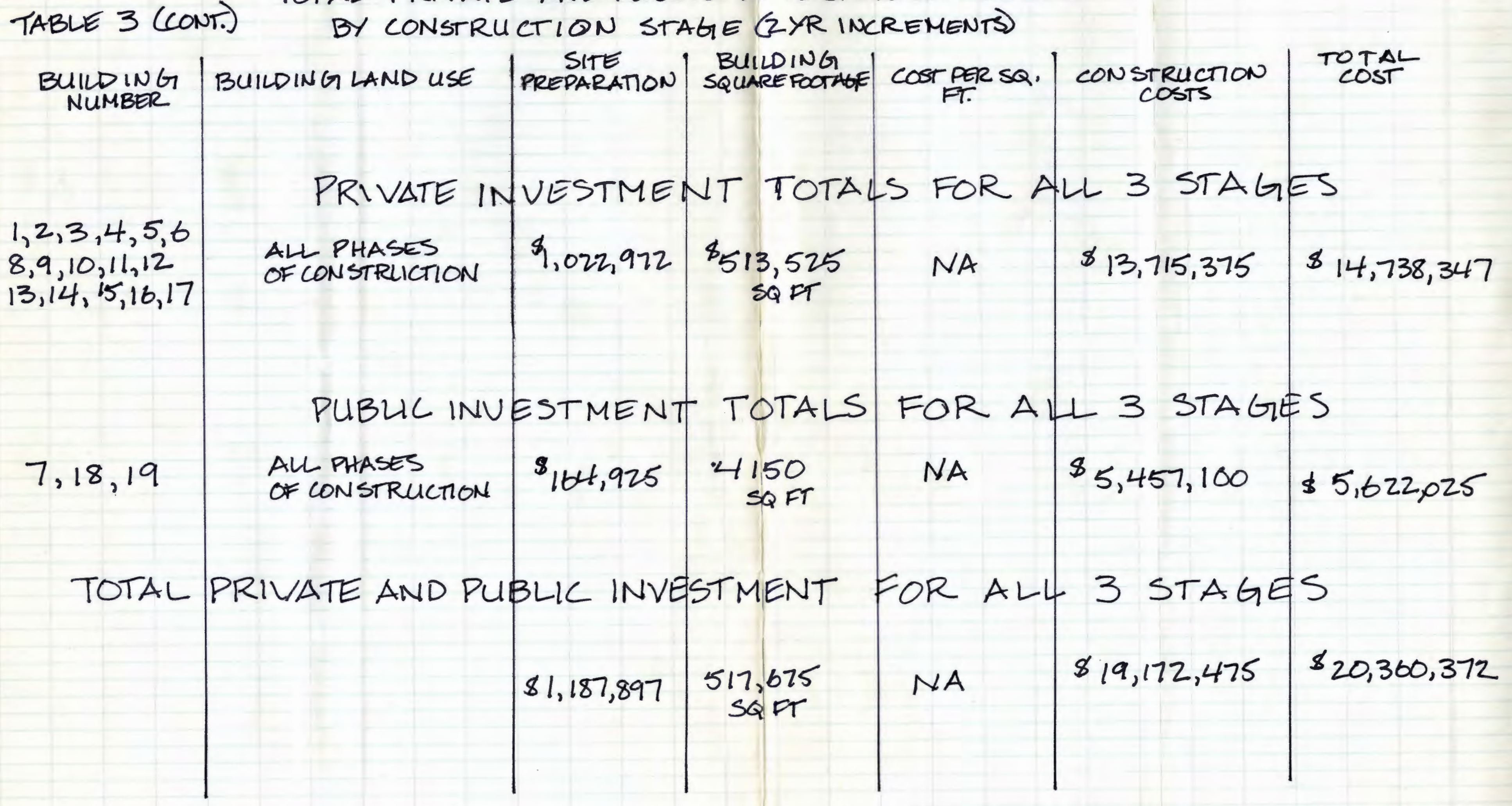


TABLE 4

ADDITIONAL COSTS TO PRIVATE CONSTRUCTION

TOTAL CONSTRUCTION COSTS FOR PRIVATE INVESTMENT DURING 3 CONSTRUCTION STAGES

ESTIMATED ADDITONAL EXPENSES

START UP COSTS

LEGAL FEES

INSURANCE

ARCHITETURAL

S ENGINEERING PEES

(BASED ON O $4.5 \%$ TOTAL)
CONSTRUCTION COST

6 YeAR INTERIM TAKEs- PREBENT TAX PER YeAR $\$ 20,118$ - ASSUME MAINTENANCE OF SAME TAX RATE UNTIL AFTER O
OF CONSTRUCTION IS FINISHED

OPPORTUNITY COSTS -ASSUME $\$ 7,880,000$ ORIGINAL INVESTMENT. 6\% INTEREST PER YEAR COMPUTES COST UNTIL FIRST YEAR OF RETURN ON INVESTMENT
$814,738,347$

25000

50000

50000

675,000

120,708

840,000

660,000

4 years at 2 POINTS ABOVE 61/4\% PRIME RATE 
TABLE 5

BUILDING NUMBER

16

$14,16,17$

11

15

12,13

4

$16,14,17,11$

12

total PRIVATE INVESTMENT INCOME ON NeW DEVELOPMENT

BUILDING LAND USE COMMERCIAL

OFFICE SPAKE

MIXED ELDERI S
LUXURY HOUSIMG

LUXURY HOUSING

PARKING BASED ON

A 2X CAPACITY TURN OVER RATE PER DAY DUE TO

PEDESTRIAN MALL \& BAY

ISLANDS PARK ACTIVITY

RECREATIONAL BUILDING

ESTIMATED POTENTIAL INCOME

DURING CONSTRULTION YEARS

DUE TO STAGED CONSTRUCTION

REOMIDENTIAL - PARKING FAC.

TOTAL INCOME POTENTIAL
SQD. FET

INCOME/SQFH

39,300
SQFT

61,525 FT

$63.000 \quad \$ 4.40 /$ SQFT $\$ 277,200$

10.000

$119,200 \quad \$ 5.04 /$ SQFT $\$ 600,768$

535

SPACES

.

$16.500 \quad 86.00 /$ sQ $\quad 899,000$

NA
$\$ 6.50 /$ SQ FT $\$ 255,450$

$\$ 7.60 / 5 Q$ FT $\$ 467,590$

r

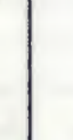

$\Phi$

$\$ 1.00 \mathrm{kPACE}$

8

390,550

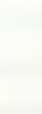

NA

$8,090,558$
INCOME FOR 20 YEARS

AFTER FINAL CONSTRUCTION

\$ $5,109,000$

$89,351,800$

$85,544,000$

$\$ 12,015,360$

$\$ 7,811,000$

$\$ 1,980,000$

$\$ 3,534,160$

$\$ 45,345,320$ 
table Total costs vs total income potential

TOTAL SITE DEVELOPMENT COSTS + TAXES OVER g VEARS OF CONSTRUCTION AND 20 YEARS

$$
\$ 35,569,259
$$

TOTAL INCOME POTENTIAL OVER G YEARS OF CONSTRUCTOr AND IO YEARS AFTER

$$
\$ 45,345,320
$$

DIFFERENCE - NET INCOME $89,776,061$

NET INCOME/TOTAL COST $27.5 \%$

ESTIMATED

GOVERNMENT COST

FEDERAL

$\$ 4,875,725$ CITY OF PROVIDENCE $\$ 746.300$ 